\title{
Pathways and genes differentially expressed in the motor cortex of patients with sporadic amyotrophic lateral sclerosis Carsten W Lederer ${ }^{1}$, Antonietta Torrisi ${ }^{2}$, Maria Pantelidou ${ }^{1}$, Niovi Santama ${ }^{1}$ and Sebastiano Cavallaro*2
}

\author{
Address: ${ }^{1}$ Department of Biological Sciences, University of Cyprus and Cyprus Institute of Neurology and Genetics, 1678 Nicosia, Cyprus and \\ ${ }^{2}$ Functional Genomics Center, Institute of Neurological Sciences, Italian National Research Council, 95123 Catania, Italy \\ Email: Carsten W Lederer - Lederer@cing.ac.cy; Antonietta Torrisi - a.torrisi@isn.cnr.it; Maria Pantelidou - mpanteli@gmail.com; \\ Niovi Santama - santama@ucy.ac.cy; Sebastiano Cavallaro* - s.cavallaro@isn.cnr.it \\ * Corresponding author
}

Published: 23 January 2007

BMC Genomics 2007, 8:26 doi:10.1186/147/-2164-8-26

This article is available from: http://www.biomedcentral.com/I47I-2/64/8/26

(C) 2007 Lederer et al; licensee BioMed Central Ltd.

This is an Open Access article distributed under the terms of the Creative Commons Attribution License (http://creativecommons.org/licenses/by/2.0), which permits unrestricted use, distribution, and reproduction in any medium, provided the original work is properly cited.
Received: 23 November 2006

Accepted: 23 January 2007

\begin{abstract}
Background: Amyotrophic lateral sclerosis (ALS) is a fatal disorder caused by the progressive degeneration of motoneurons in brain and spinal cord. Despite identification of disease-linked mutations, the diversity of processes involved and the ambiguity of their relative importance in ALS pathogenesis still represent a major impediment to disease models as a basis for effective therapies. Moreover, the human motor cortex, although critical to ALS pathology and physiologically altered in most forms of the disease, has not been screened systematically for therapeutic targets.
\end{abstract}

Results: By whole-genome expression profiling and stringent significance tests we identify genes and gene groups de-regulated in the motor cortex of patients with sporadic ALS, and interpret the role of individual candidate genes in a framework of differentially expressed pathways. Our findings emphasize the importance of defense responses and cytoskeletal, mitochondrial and proteasomal dysfunction, reflect reduced neuronal maintenance and vesicle trafficking, and implicate impaired ion homeostasis and glycolysis in ALS pathogenesis. Additionally, we compared our dataset with publicly available data for the SALS spinal cord, and show a high correlation of changes linked to the diseased state in the SALS motor cortex. In an analogous comparison with data for the Alzheimer's disease hippocampus we demonstrate a low correlation of global changes and a moderate correlation for changes specifically linked to the SALS diseased state.

Conclusion: Gene and sample numbers investigated allow pathway- and gene-based analyses by established error-correction methods, drawing a molecular portrait of the ALS motor cortex that faithfully represents many known disease features and uncovers several novel aspects of ALS pathology. Contrary to expectations for a tissue under oxidative stress, nuclear-encoded mitochondrial genes are uniformly down-regulated. Moreover, the down-regulation of mitochondrial and glycolytic genes implies a combined reduction of mitochondrial and cytoplasmic energy supply, with a possible role in the death of ALS motoneurons. Identifying candidate genes exclusively expressed in non-neuronal cells, we also highlight the importance of these cells in disease development in the motor cortex. Notably, some pathways and candidate genes identified by this study are direct or indirect targets of medication already applied to unrelated illnesses and point the way towards the rapid development of effective symptomatic ALS therapies. 


\section{Background}

Amyotrophic lateral sclerosis (ALS) is a fatal neuromuscular disorder affecting 1-2 in 100,000 persons. It is caused by the degeneration of motoneurons in brain and spinal cord, leading to muscle atrophy, progressive paralysis, and death, commonly by respiratory failure. Most cases of ALS are sporadic (SALS) and about $10 \%$ familial (FALS), with mutant forms of copper-zinc superoxide dismutase (SOD1) causing $20 \%$ of FALS cases. Findings in ALS patients and model systems have implicated numerous genes in ALS pathogenesis, and have identified diverse processes, such as oxidative stress, excitotoxicity, mitochondrial dysfunction, protein aggregation, cytoskeletal abnormalities, impaired axonal transport, inflammation, and apoptosis, as contributing factors [1]. As a mainly sporadic disease affecting multiple cellular processes, ALS therefore suggests itself for comprehensive expression profiling and gene- and pathway-based analyses. The few existing genomics studies of ALS [2-4], however, have had limited genome coverage and have been restricted to gene-based analyses.

Adding a further layer of complexity, ALS is a highly heterogenous disease, with clinical indicators helping to define ALS subtypes. One such indicator is a differential depletion of motoneurons in motor cortex and spinal cord [5-7], giving significance to the characterization of both tissues. The motor cortex contains upper motoneurons (UMNs), which extend axons traversing the corticospinal tract to signal to the spinal cord, where lower motoneurons (LMNs) relay their signal. The corticospinal tract volume is reduced [8] and UMNs are depleted $[9,10]$ in ALS patients, and UMNs are required for LMN function and muscle control [11]. Most importantly, patients with sporadic, non-SOD1-associated forms of ALS show alterations in the motor cortex, such as increased excitability and reduced inhibitory activity, which are not readily detectable in SOD1-linked FALS patients, thus stressing the particular importance of investigating the motor cortex in SALS subjects [12-14]. Possibly owing to earlier clinical manifestations of defects in LMNs and their easier accessibility to experimenters, however, most investigations of ALS, including previous genomics studies [2-4], focus on the spinal cord and LMNs, leaving ALS-related responses and defects of cellular maintenance in the motor cortex under-investigated.

Here we address the importance of UMN abnormalities in SALS pathology and exploit the power of pathway-based significance tests by whole-genome expression profiling of the motor cortex of SALS patients. We identify differentially expressed genes and pathways, interpret the role of candidate genes in ALS pathology using these pathways as a functional outline, and evaluate the implications of our findings for ALS research and the development of ALS therapies.

\section{Results}

Expression profiling of the motor cortex of SALS patients We investigated the motor cortex of eleven SALS and nine control subjects (see Table 1) with whole-genome oligonucleotide microarrays and following microscopic assessment of tissue architecture (see Figure 1 for Nissl staining of six representative samples). Out of over 41,000 genes and expressed sequence tags tested, 19,431 genes passed our quality control criteria (see the Methods section), constituting our complete data set for subsequent analyses. Median and average fold-changes of our complete data set were 1.01 (Diseased vs. Control), establishing that no systematic bias for up- or down-regulation was introduced into subsequent statistical analyses.

To exploit the comprehensiveness of our data, we combined two complementary, stringent approaches, investigating changes in the SALS motor cortex for functional gene groups and on the level of individual genes.

\section{Pathway-based analysis}

We first performed a pathway-based analysis of the complete data set by testing changes of gene expression in the context of 5137 gene groups of the gene ontology (GO) hierarchy, using the GenMAPP 2.0 software. Analyses on the level of functional gene groups lead to a biologically transparent picture of expression, accessible to interpretation. What is more, by combining measurements for functionally related genes this approach increases the sensitivity of detecting significant changes when differential gene expression is diluted in a mixed cell population (leading to comparably low fold changes) and with small to moderate sample numbers (possibly leading to a high variance for inconsistently de-regulated genes). In such instances individual genes will not pass statistical criteria for differential gene expression, while moderate deregulation of multiple genes constituting a functional group might test highly significant. Indeed, the statistical significances we derived from GenMAPP 2.0, using the average fold-change per gene as a basis for statistical tests, is independent of the number of samples and highly dependent on the number of genes represented by our data, while the quality filtering and the comparably large number of samples used in this study avoid the detection of spurious results and promote a correspondence between statistical and biological significance. In other words, 5137 GO categories were probed with 19,431 quality filtered genes, and 20 samples were used to derive representative average fold-changes to do so. GenMAPP detected 5033 GO categories as unchanged, while 104 partially redundant categories exhibited significantly changed expression in ALS subjects (corrected $P<0.05$ ). Significant GO categories 
Table I: Characteristics of subjects

\begin{tabular}{|c|c|c|c|c|c|c|c|c|}
\hline Sample ID & $\begin{array}{c}\text { Sample } \\
\text { Type }\end{array}$ & Order Code & Chief Disease & Cause of Death & $\begin{array}{c}\text { Age } \\
\text { [years/days] }\end{array}$ & Gender & Race & PMI [h] \\
\hline Control I & tissue & BTB3428 A & drowning & drowning & $56 / 275$ & Female & Caucasian & 17 \\
\hline Control 2 & tissue & BTB3576A & hypertension & $\begin{array}{l}\text { ruptured abdominal } \\
\text { aortic aneurism }\end{array}$ & $59 / 260$ & Male & Caucasian & 15 \\
\hline Control 3 & tissue & BTB3577A & $\mathrm{n} / \mathrm{a}$ & $\mathrm{n} / \mathrm{a}$ & $59 / 118$ & Male & Caucasian & 21 \\
\hline Control 4 & tissue & BTB3688A & $\begin{array}{l}\text { ascending colon } \\
\text { adenocarcinoma }\end{array}$ & $\begin{array}{l}\text { ascending colon } \\
\text { adenocarcinoma }\end{array}$ & $60 /-$ & Male & Hispanic White & 17 \\
\hline Control 5 & tissue & HCtANA & $\mathrm{n} / \mathrm{a}$ & $\mathrm{n} / \mathrm{a}$ & $72 /-$ & Male & Caucasian & 11 \\
\hline Control 6 & tissue & HCtAVA & $\mathrm{n} / \mathrm{a}$ & $\mathrm{n} / \mathrm{a}$ & $84 /-$ & Female & Caucasian & 2.75 \\
\hline Control 7 & tissue & HCtEUA & $\begin{array}{c}\text { coronary artery } \\
\text { disease }\end{array}$ & $\mathrm{n} / \mathrm{a}$ & $79 /-$ & Female & Caucasian & 7.5 \\
\hline Control 8 & tissue & $\mathrm{HCtFMA}^{\mathrm{A}}$ & $\mathrm{n} / \mathrm{a}$ & $\mathrm{n} / \mathrm{a}$ & $70 /-$ & Female & Caucasian & 8.5 \\
\hline Control 9 & RNA & $6782^{B}$ & $\begin{array}{l}\text { thrombosis and } \\
\text { coronary } \\
\text { atherosclerosis }\end{array}$ & heart attack & $68 /-$ & Male & Caucasian & $\mathrm{n} / \mathrm{a}$ \\
\hline Diseased I & tissue & BTB3226 A & ALS & $\begin{array}{l}\text { respiratory failure } \\
\text { with probable early } \\
\text { pneumonia }\end{array}$ & $71 / 18$ & Male & Caucasian & 19 \\
\hline Diseased 2 & tissue & BTB3235 A & ALS & respiratory failure & $73 / 106$ & Male & Caucasian & 5.5 \\
\hline Diseased 3 & tissue & BTB346I A & ALS & ALS & $77 / 53$ & Male & Caucasian & 7.5 \\
\hline Diseased 4 & tissue & ВTВ3580A & ALS & respiratory failure & $58 / 83$ & Male & Caucasian & 22 \\
\hline Diseased 5 & tissue & BTB3583A & ALS & respiratory distress & $52 / 54$ & Female & Hispanic White & 20.5 \\
\hline Diseased 6 & tissue & ВТВ3590A & ALS & pneumonia & $75 /-$ & Male & Caucasian & 24 \\
\hline Diseased 7 & tissue & ВTВ3603А & ALS & N/A & $67 / 325$ & Female & Caucasian & 17 \\
\hline Diseased 8 & tissue & BTB36IIA & ALS & N/A & $69 / 90$ & Female & Caucasian & 13 \\
\hline Diseased 9 & tissue & BTB3689A & ALS & N/A & $61 / 141$ & Female & Caucasian & 22 \\
\hline Diseased 10 & tissue & BTB37I $3^{A}$ & ALS & ALS & $66 / 252$ & Male & Caucasian & 13 \\
\hline Diseased II & RNA & $6166^{B}$ & ALS & respiratory failure & 70/- & Male & Caucasian & $\mathrm{n} / \mathrm{a}$ \\
\hline
\end{tabular}

20 motor-cortex samples of eleven ALS patients and nine controls were analyzed on individual Whole Human Genome Arrays for genome-wide expression profiling. Age, gender, race, and post-mortem interval (mean controls $12.47 \pm 6.06 \mathrm{~h}$ and mean patients $16.35 \pm 6.37 \mathrm{~h}, P=0.2 \mathrm{I}$ ) are shown for all tissue samples. A - Miami Brain and Tissue Bank for Developmental Disorders; B - Ambion, Inc.; n/a - not available

fell into six major processes of relevance in the context of a comprehensive ALS disease model, five of them downregulated and one up-regulated (Figure 2; see Table 2 for the full list of significantly changed GO categories).

\section{Identification of candidate genes}

We then analyzed the complete data set for individual genes showing differential gene expression, finding that 57 of the 19,431 quality-filtered genes (0.3\%) fulfilled our stringent criteria (including Benjamini and Hochberg multiple testing correction, for details see the Methods section), with 40 genes showing down-regulation and 17 upregulation in SALS subjects (Figure 3). In contrast to results for large gene groups, differential expression of individual mRNAs is readily verifiable by alternative techniques, such as quantitative RT-PCR (qRT-PCR) and insitu hybridization.

\section{Confirmation by quantitative RT-PCR}

The 60-mer oligonucleotide format of microarrays used in this study may provide tolerance for sequence mis- matches. To investigate probe-target specificity, the sequences of oligonucleotide probes corresponding to differentially expressed genes were compared to GenBank sequences by BLASTN queries. The only probes showing up to ten mismatches with more than one gene were seven metallothioneins (MT1B, MT1E, MT1G, MT1L, MT1M, MT1X, MT2A). To discriminate among these homologous genes and analyze their differential expression we used qRT-PCR. PVALB, down-regulated in the ALS motor cortex, was also included in our qRT-PCR analysis as a positive control for the correspondence of microarray and qRT-PCR data. In contrast to the metallothionein probes the PVALB probe, representative of probes for the remaining candidates, detects transcripts for a single gene, only. PVALB and six of the metallothioneins were specifically quantifiable by qRT-PCR (Figure 4). Microarray and qRTPCR results were concordant (correlation coefficient $\mathrm{r}=$ 0.91, comparing individual test and control averages for the seven genes tested), confirming up-regulation of six metallothioneins and down-regulation of PVALB in the SALS motor cortex. MT1B, whose microarray probe shares 


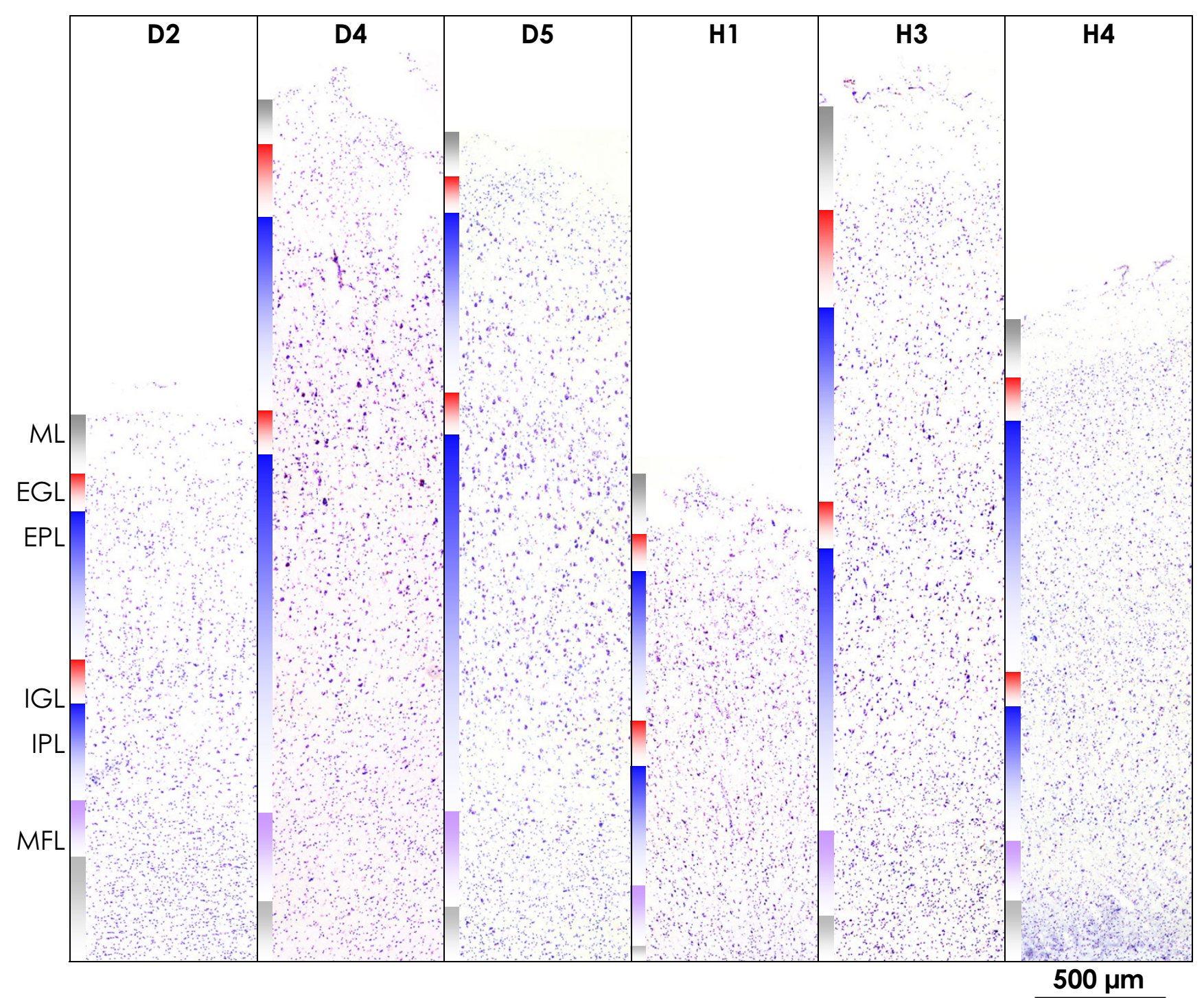

Figure I

Architecture of the motor cortex in SALS and control samples. Nissl staining of representative SALS samples (D2, D4, D5) and controls ( $\mathrm{HI}, \mathrm{H3}, \mathrm{H} 4)$ shows the intact architecture of the motor cortex in samples chosen for expression analysis. All samples are shown at identical magnification. Cell layers are color-coded as indicated for sample D2. ML-molecular layer; EGL - external granular layer; EPL - external pyramidal layer; IGL - internal granular layer; IPL - internal Pyramidal layer; MFL - multiform layer; WM - white matter. The scale bar indicates $500 \mu \mathrm{m}$.

$87 \%$ sequence identity with $M T 1 L$, could not be detected specifically by three independent primer pairs, and was excluded from subsequent analyses.

\section{Confirmation by in-situ hybrization}

To verify the microarray results in a direct fashion (i.e. without intervening reverse-transcription and amplification steps), we then performed double-blind in-situ hybridization for four candidate genes in human motor cortex sections from five control and five SALS subjects. Median fluorescence levels of entire tissue sections for dis- eased and control subjects were measured for four candidate genes (ANXA2, ATP1A3, NRGN, and PVALB, see Figure 5), showing a strong correlation with the microarray data (correlation coefficient $r=0.97$, comparing individual test and control averages for the four genes tested).

\section{Confirmation at the protein level}

We then proceeded to validate our findings for mRNAs at the level of proteins, which for the overwhelming majority of RNAs investigated in this study represent the biolog- 


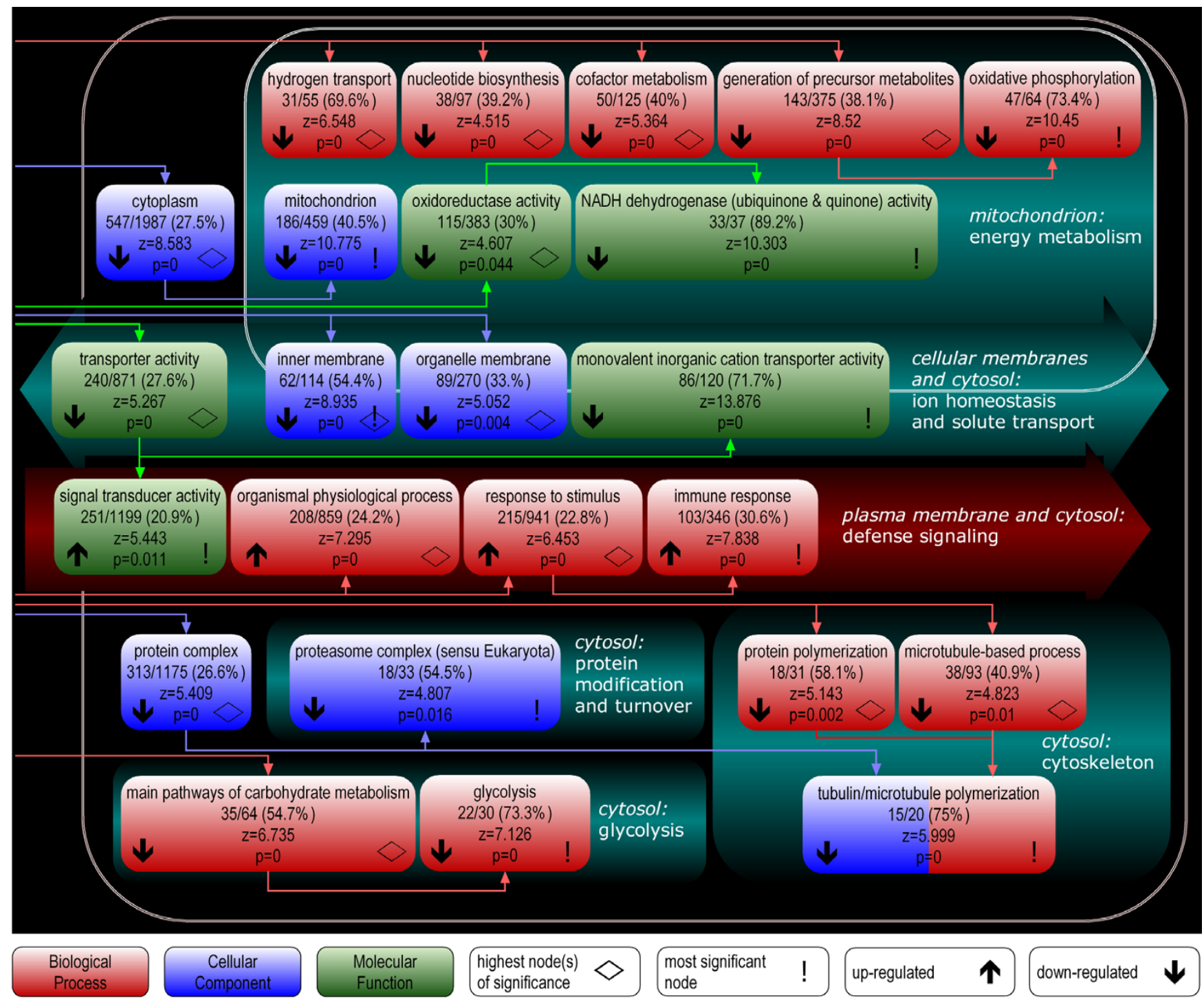

\section{Figure 2}

Gene Ontology nodes differentially expressed in motor cortex of SALS subjects. Significant Gene Ontology (GO) nodes were combined to groups likely representing major processes in the context of ALS pathology, specifically energy metabolism, ion homeostasis and solute transport, defense signaling, protein modification and turnover, cytoskeleton, and glycolysis, and are arranged indicating the predominant intracellular localization of the gene products they comprise. The basic categories Biological Process, Cellular Component, and Molecular Function are color-coded. Connecting arrows indicate the order of nodes in the GO hierarchy. For each major process only the highest node(s) of significance $(\diamond)$ and the most significant node (!) are shown per basic category. Up- $(\boldsymbol{N})$ and down-regulation $(\boldsymbol{V})$, the absolute number and percentage of genes meeting the criterion, $z$ score, and corrected $P$ value are indicated for each node. Redundant nodes are left out within the same category, or combined if in different categories.

ically active equivalent. While individual genes may show discrepancies between mRNA and protein levels, owing to translational and post-translational control, an on average fair correlation between protein and mRNA levels can be expected in mammalian systems [15]. Protein extracts of three healthy and six diseased samples, equalized for total protein content, were analyzed by immunoblotting (see Figure $6 \mathrm{~A}$ and $6 \mathrm{~B}$ ). Quantification of protein levels revealed an up-regulation for ANXA2 (18.56-fold) and AQP1 (4.94-fold), and a down-regulation of NRGN (0.38-fold) in diseased samples. These findings were in line with and exceeded the fold-changes of 2.06, 2.52, and 
Table 2: Differentially regulated GO categories

\begin{tabular}{|c|c|c|c|c|c|c|c|}
\hline \multicolumn{8}{|c|}{ Up-regulated GO categories } \\
\hline GO ID & Go Name & GO Type & $\begin{array}{l}\text { Number } \\
\text { Changed }\end{array}$ & $\begin{array}{l}\text { Number } \\
\text { Measured }\end{array}$ & $\begin{array}{l}\text { Percent } \\
\text { Changed }\end{array}$ & z Score & corrected $P$ \\
\hline 6955 & immune response & BP & 106 & 346 & 30.64 & 7.84 & 0 \\
\hline 9607 & response to biotic stimulus & BP & 130 & 456 & 28.51 & 7.77 & 0 \\
\hline 6952 & defense response & $\mathrm{BP}$ & 113 & 381 & 29.66 & 7.71 & 0 \\
\hline 50874 & organismal physiological process & BP & 208 & 859 & 24.21 & 7.30 & 0 \\
\hline 50896 & response to stimulus & $\mathrm{BP}$ & 215 & 941 & 22.85 & 6.45 & 0 \\
\hline 43207 & response to external biotic stimulus & $\mathrm{BP}$ & 71 & 235 & 30.21 & 6.24 & 0 \\
\hline 9613 & response to pestl, pathogen or parasite & $\mathrm{BP}$ & 69 & 228 & 30.26 & 6.16 & 0 \\
\hline 9605 & response to external stimulus & $\mathrm{BP}$ & 134 & 563 & 23.80 & 5.51 & 0.01 \\
\hline 4871 & signal transducer activity & MF & 251 & 1199 & 20.93 & 5.44 & 0.011 \\
\hline 9596 & detection of pestl, pathogen or parasite & $\mathrm{BP}$ & 5 & 5 & 100.00 & 5.19 & 0.047 \\
\hline
\end{tabular}

2453 probes met the [fold-change] $>=1.2$ criterion.

1782 probes meeting the filter linked to an Ensembl ID.

1323 genes meeting the criterion linked to a GO term.

The $\mathrm{z}$ score is based on an N of 8457 and an R of I 323 distinct genes in the GO.

\begin{tabular}{|c|c|c|c|c|c|c|c|}
\hline \multicolumn{8}{|c|}{ Down-regulated GO categories } \\
\hline GO ID & GO Name & GO Type & $\begin{array}{l}\text { Number } \\
\text { Changed }\end{array}$ & $\begin{array}{l}\text { Number } \\
\text { Measured }\end{array}$ & $\begin{array}{l}\text { Percent } \\
\text { Changed }\end{array}$ & z Score & corrected $P$ \\
\hline 15077 & monovalent inorganic cation transporter activity & MF & 86 & 120 & 71.67 & 13.88 & 0 \\
\hline 15078 & hydrogen ion transporter activity & MF & 80 & 111 & 72.07 & 13.44 & 0 \\
\hline 15399 & primary active transporter activity & MF & 88 & $|3|$ & 67.18 & 13.23 & 0 \\
\hline 16655 & $\begin{array}{l}\text { oxidoreductase activityl, acting on NADH or NADPHI, } \\
\text { quinone or similar compound as acceptor }\end{array}$ & MF & 37 & 42 & 88.10 & 10.81 & 0 \\
\hline 5739 & mitochondrion & $\mathrm{CC}$ & 186 & 459 & 40.52 & 10.78 & 0 \\
\hline 3954 & NADH dehydrogenase activity & MF & 34 & 38 & 89.47 & 10.49 & 0 \\
\hline 6119 & oxidative phosphorylation & $\mathrm{BP}$ & 47 & 64 & 73.44 & 10.45 & 0 \\
\hline 50136 & NADH dehydrogenase (quinone) activity & MF & 33 & 37 & 89.19 & 10.30 & 0 \\
\hline 8137 & NADH dehydrogenase (ubiquinone) activity & MF & 33 & 37 & 89.19 & 10.30 & 0 \\
\hline $1665 \mid$ & oxidoreductase activityl, acting on NADH or NADPH & MF & 43 & 57 & 75.44 & 10.23 & 0 \\
\hline$|508|$ & sodium ion transporter activity & MF & 34 & 40 & 85.00 & 10.06 & 0 \\
\hline 19866 & inner membrane & $\mathrm{CC}$ & 62 & 114 & 54.39 & 8.94 & 0 \\
\hline 42775 & $\begin{array}{l}\text { ATP synthesis coupled electron transport (sensu } \\
\text { Eukaryota) }\end{array}$ & $\mathrm{BP}$ & 22 & 24 & 91.67 & 8.59 & 0 \\
\hline 5737 & cytoplasm & $\mathrm{CC}$ & 547 & 1987 & 27.53 & 8.58 & 0 \\
\hline 6091 & generation of precursor metabolites and energy & $\mathrm{BP}$ & 143 & 375 & 38.13 & 8.52 & 0 \\
\hline 8324 & cation transporter activity & MF & 127 & 324 & 39.20 & 8.38 & 0 \\
\hline 42773 & ATP synthesis coupled electron transport & BP & 22 & 25 & 88.00 & 8.32 & 0 \\
\hline 5740 & mitochondrial membrane & $\mathrm{CC}$ & 59 & 115 & 51.30 & 8.15 & 0 \\
\hline 46873 & metal ion transporter activity & MF & 42 & 70 & 60.00 & 8.15 & 0 \\
\hline 15075 & ion transporter activity & MF & 146 & 397 & 36.78 & 8.10 & 0 \\
\hline 5386 & carrier activity & MF & 109 & 271 & 40.22 & 8.06 & 0 \\
\hline 6120 & mitochondrial electron transportl, NADH to ubiquinone & $\mathrm{BP}$ & 19 & 21 & 90.48 & 7.90 & 0 \\
\hline 5743 & mitochondrial inner membrane & $\mathrm{CC}$ & 48 & 89 & 53.93 & 7.78 & 0 \\
\hline 6096 & glycolysis & $\mathrm{BP}$ & 22 & 30 & 73.33 & 7.13 & 0 \\
\hline 6754 & ATP biosynthesis & $\mathrm{BP}$ & 26 & 41 & 63.41 & 6.77 & 0 \\
\hline 6753 & nucleoside phosphate metabolism & BP & 26 & 41 & 63.41 & 6.77 & 0 \\
\hline 9206 & purine ribonucleoside triphosphate biosynthesis & $\mathrm{BP}$ & 30 & 51 & 58.82 & 6.74 & 0 \\
\hline 9145 & purine nucleoside triphosphate biosynthesis & BP & 30 & 51 & 58.82 & 6.74 & 0 \\
\hline 9201 & ribonucleoside triphosphate biosynthesis & $\mathrm{BP}$ & 30 & 51 & 58.82 & 6.74 & 0 \\
\hline 6092 & main pathways of carbohydrate metabolism & $\mathrm{BP}$ & 35 & 64 & 54.69 & 6.74 & 0 \\
\hline 15992 & proton transport & $\mathrm{BP}$ & 31 & 54 & 57.41 & 6.68 & 0 \\
\hline 16818 & $\begin{array}{l}\text { hydrolase activityl, acting on acid anhydridesl, in } \\
\text { phosphorus-containing anhydrides }\end{array}$ & MF & 124 & 358 & 34.64 & 6.65 & 0 \\
\hline 16817 & hydrolase activityl, acting on acid anhydrides & MF & 124 & 358 & 34.64 & 6.65 & 0 \\
\hline 9142 & nucleoside triphosphate biosynthesis & $\mathrm{BP}$ & 30 & 52 & 57.69 & 6.60 & 0 \\
\hline
\end{tabular}


Table 2: Differentially regulated GO categories (Continued)

\begin{tabular}{|c|c|c|c|c|c|c|c|}
\hline 15405 & P-P-bond-hydrolysis-driven transporter activity & MF & 36 & 68 & 52.94 & 6.59 & 0 \\
\hline 9199 & ribonucleoside triphosphate metabolism & $\mathrm{BP}$ & 31 & 55 & 56.36 & 6.55 & 0 \\
\hline 9144 & purine nucleoside triphosphate metabolism & $\mathrm{BP}$ & 31 & 55 & 56.36 & 6.55 & 0 \\
\hline 6818 & hydrogen transport & $\mathrm{BP}$ & 31 & 55 & 56.36 & 6.55 & 0 \\
\hline 9205 & purine ribonucleoside triphosphate metabolism & $\mathrm{BP}$ & 31 & 55 & 56.36 & 6.55 & 0 \\
\hline 46034 & ATP metabolism & $\mathrm{BP}$ & 27 & 45 & 60.00 & 6.52 & 0 \\
\hline 16462 & pyrophosphatase activity & MF & 122 & 356 & 34.27 & 6.45 & 0 \\
\hline 46961 & $\begin{array}{l}\text { hydrogen-transporting ATPase activityl, rotational } \\
\text { mechanism }\end{array}$ & MF & 23 & 36 & 63.89 & 6.41 & 0 \\
\hline 16469 & proton-transporting two-sector ATPase complex & $\mathrm{CC}$ & 23 & 36 & 63.89 & 6.41 & 0 \\
\hline 9152 & purine ribonucleotide biosynthesis & $\mathrm{BP}$ & 33 & 62 & 53.23 & 6.34 & 0 \\
\hline 9141 & nucleoside triphosphate metabolism & $\mathrm{BP}$ & 31 & 57 & 54.39 & 6.30 & 0 \\
\hline 15985 & $\begin{array}{l}\text { energy coupled proton transportl, down electrochemical } \\
\text { gradient }\end{array}$ & $\mathrm{BP}$ & 23 & 37 & 62.16 & 6.24 & 0 \\
\hline 6007 & glucose catabolism & $\mathrm{BP}$ & 23 & 37 & 62.16 & 6.24 & 0 \\
\hline 15986 & ATP synthesis coupled proton transport & $\mathrm{BP}$ & 23 & 37 & 62.16 & 6.24 & 0 \\
\hline 15980 & energy derivation by oxidation of organic compounds & $\mathrm{BP}$ & 46 & 101 & 45.54 & 6.20 & 0 \\
\hline 5489 & electron transporter activity & MF & 67 & 168 & 39.88 & 6.20 & 0 \\
\hline 45259 & proton-transporting ATP synthase complex & $\mathrm{CC}$ & 10 & 10 & 100.00 & 6.19 & 0 \\
\hline 45255 & hydrogen-translocating F-type ATPase complex & $\mathrm{CC}$ & 10 & 10 & 100.00 & 6.19 & 0 \\
\hline 5753 & $\begin{array}{l}\text { proton-transporting ATP synthase complex (sensu } \\
\text { Eukaryota) }\end{array}$ & $\mathrm{CC}$ & 10 & 10 & 100.00 & 6.19 & 0 \\
\hline 46933 & $\begin{array}{l}\text { hydrogen-transporting ATP synthase activityl, rotational } \\
\text { mechanism }\end{array}$ & MF & 22 & 35 & 62.86 & 6.17 & 0 \\
\hline 42625 & $\begin{array}{l}\text { ATPase activityl, coupled to transmembrane movement } \\
\text { of ions }\end{array}$ & MF & 32 & 61 & 52.46 & 6.14 & 0 \\
\hline 19829 & cation-transporting ATPase activity & MF & 23 & 38 & 60.53 & 6.07 & 0 \\
\hline$|7| 1 \mid$ & nucleoside-triphosphatase activity & MF & 114 & 338 & 33.73 & 6.03 & 0 \\
\hline 9150 & purine ribonucleotide metabolism & $\mathrm{BP}$ & 33 & 65 & 50.77 & 6.01 & 0 \\
\hline 6164 & purine nucleotide biosynthesis & $\mathrm{BP}$ & 33 & 65 & 50.77 & 6.01 & 0 \\
\hline 45298 & tubulin & $\mathrm{BP}$ & 15 & 20 & 75.00 & 6.00 & 0 \\
\hline 46785 & microtubule polymerization & $\mathrm{CC}$ & 15 & 20 & 75.00 & 6.00 & 0 \\
\hline 9260 & ribonucleotide biosynthesis & $\mathrm{BP}$ & 33 & 66 & 50.00 & 5.90 & 0 \\
\hline 31109 & microtubule polymerization or depolymerization & $\mathrm{BP}$ & 17 & 25 & 68.00 & 5.84 & 0 \\
\hline 9259 & ribonucleotide metabolism & $\mathrm{BP}$ & 34 & 70 & 48.57 & 5.78 & 0 \\
\hline 46164 & alcohol catabolism & $\mathrm{BP}$ & 23 & 40 & 57.50 & 5.76 & 0 \\
\hline 46365 & monosaccharide catabolism & BP & 23 & 40 & 57.50 & 5.76 & 0 \\
\hline 19320 & hexose catabolism & $\mathrm{BP}$ & 23 & 40 & 57.50 & 5.76 & 0 \\
\hline 6752 & group transfer coenzyme metabolism & $\mathrm{BP}$ & 27 & 51 & 52.94 & 5.70 & 0 \\
\hline 6163 & purine nucleotide metabolism & $\mathrm{BP}$ & 33 & 68 & 48.53 & 5.69 & 0 \\
\hline 15002 & heme-copper terminal oxidase activity & MF & 13 & 17 & 76.47 & 5.68 & 0 \\
\hline 16676 & $\begin{array}{l}\text { oxidoreductase activityl, acting on heme group of } \\
\text { donorsl, oxygen as acceptor }\end{array}$ & MF & 13 & 17 & 76.47 & 5.68 & 0 \\
\hline 16675 & oxidoreductase activityl, acting on heme group of donors & MF & 13 & 17 & 76.47 & 5.68 & 0 \\
\hline 4129 & cytochrome-c oxidase activity & MF & 13 & 17 & 76.47 & 5.68 & 0 \\
\hline 6732 & coenzyme metabolism & $\mathrm{BP}$ & 45 & 107 & 42.06 & 5.49 & 0 \\
\hline 42626 & $\begin{array}{l}\text { ATPase activityl, coupled to transmembrane movement } \\
\text { of substances }\end{array}$ & MF & 36 & 79 & 45.57 & 5.48 & 0 \\
\hline 16820 & $\begin{array}{l}\text { hydrolase activity\, acting on acid anhydrides\, catalyzing } \\
\text { transmembrane movement of substances }\end{array}$ & MF & 36 & 79 & 45.57 & 5.48 & 0 \\
\hline 43234 & protein complex & $\mathrm{CC}$ & 313 & 1175 & 26.64 & 5.41 & 0 \\
\hline 51186 & cofactor metabolism & $\mathrm{BP}$ & 50 & 125 & 40.00 & 5.36 & 0 \\
\hline 6006 & glucose metabolism & $\mathrm{BP}$ & 27 & 54 & 50.00 & 5.33 & 0 \\
\hline 5215 & transporter activity & MF & 240 & 871 & 27.55 & 5.27 & 0 \\
\hline 45333 & cellular respiration & $\mathrm{BP}$ & 17 & 28 & 60.71 & 5.23 & 0 \\
\hline 51258 & protein polymerization & BP & 18 & 31 & 58.06 & 5.14 & 0.002 \\
\hline 226 & microtubule cytoskeleton organization and biogenesis & $\mathrm{BP}$ & 25 & 50 & 50.00 & 5.13 & 0.004 \\
\hline 31090 & organelle membrane & $\mathrm{CC}$ & 89 & 270 & 32.96 & 5.05 & 0.004 \\
\hline 7017 & microtubule-based process & $\mathrm{BP}$ & 38 & 93 & 40.86 & 4.82 & 0.01 \\
\hline 502 & proteasome complex (sensu Eukaryota) & $\mathrm{CC}$ & 18 & 33 & 54.55 & 4.81 & 0.016 \\
\hline 16052 & carbohydrate catabolism & $\mathrm{BP}$ & 24 & 50 & 48.00 & 4.78 & 0.025 \\
\hline 44275 & cellular carbohydrate catabolism & BP & 24 & 50 & 48.00 & 4.78 & 0.025 \\
\hline 9117 & nucleotide metabolism & $\mathrm{BP}$ & 48 & 128 & 37.50 & 4.73 & 0.026 \\
\hline
\end{tabular}


Table 2: Differentially regulated GO categories (Continued)

\begin{tabular}{|c|c|c|c|c|c|c|c|}
\hline 6118 & electron transport & $\mathrm{BP}$ & 73 & 220 & 33.18 & 4.63 & 0.043 \\
\hline 3924 & GTPase activity & MF & 44 & 116 & 37.93 & 4.61 & 0.043 \\
\hline |649| & oxidoreductase activity & MF & 115 & 383 & 30.03 & 4.61 & 0.044 \\
\hline 5829 & cytosol & $\mathrm{CC}$ & 69 & 207 & 33.33 & 4.54 & 0.045 \\
\hline 9165 & nucleotide biosynthesis & BP & 38 & 97 & 39.18 & 4.52 & 0.045 \\
\hline
\end{tabular}

3059 probes met the [fold-change] $<=(\mathrm{I} / \mathrm{I} .2)$ criterion.

2522 probes meeting the filter linked to an Ensembl ID.

175I genes meeting the criterion linked to a GO term.

The $\mathrm{z}$ score is based on an $\mathrm{N}$ of 8457 and an R of 175 I distinct genes in the GO.

Shown are all GO nodes differentially regulated between SALS motor-cortex-patient samples and controls for the comprehensive dataset. Of 19,43 I probes in the dataset, 8,457 were linked to a GO term. Nodes are sorted by up- or down-regulation (top and bottom sub-tables, respectively), then sorted by corrected $P$ value (lowest first) and $z$ value (highest first). CC - cellular component; MF - molecular function; BP biological process

0.49, respectively, detected by microarray-based analysis for the corresponding mRNAs. Remarkably, AQP1 is generally assumed to be absent from the motor cortex, with a predominant expression in the brain in the choroid plexus [16] and in glial cells in the peripheral nervous system [17]. We therefore also performed immunofluorescence analyses of motor-cortical sections to elaborate our findings (Figure 6C), demonstrating the presence of AQP1 in non-neuronal cells in the motor cortex.

\section{Comparison with SALS spinal-cord and AD hippocampus expression data}

We then compared expression ratios diseased vs. control for the SALS motor cortex to previously published data for spinal cord grey matter [4]. A comparison of all 2266 genes reliably detected in both tissues showed a negligible correlation $(\mathrm{r}=0.04)$, while 23 of the motor-cortex candidate genes also present in the reduced data set showed a high correlation $(\mathrm{r}=0.85)$ between both tissues (see the Methods section and Table 3).

To assess in how far responses detected in the motor cortex of SALS patients might be shared with other neurodegenerative diseases, we then compared our data to expression ratios diseased vs. healthy for previously published data by Blalock et al. [18] for the hippocampus of patients with severe Alzheimer's disease (AD). A comparison of all 6375 genes reliably detected in both tissues showed a low correlation $(\mathrm{r}=0.38)$, while 38 of the motor-cortex candidate genes also present in the reduced data set showed a moderate correlation $(r=0.70)$ between both tissues (see the Methods section and Table 4).

Despite the distinctive clinical manifestations of $\mathrm{AD}$ and its action on different areas of the central nervous system, therefore, global responses in the AD hippocampus correspond more closely to those in the SALS motor cortex than do those in the SALS spinal cord. This observation might reflect similar general changes in both brain tissues under long-term stress and after prolonged disease pathol- ogy, and ties in with the implication of processes such as oxidative stress, reduced energy metabolism, intracellular protein aggregation, and inflammation in both, AD and ALS pathogenesis. Importantly and similar to our findings for the SALS motor cortex, Blalock et al. [18] detected ATP biosynthesis and glycolysis by pathway-based analysis as significantly reduced in $\mathrm{AD}$, and found deregulation in line with ours for defense response and microtubule-based process, albeit below the significance threshold. Changes significantly linked to the diseased state in our study, however, are highly correlated between SALS motor cortex and spinal cord, and less similar between SALS motor cortex and AD hippocampus. In particular, ATP1A3, EGR1, and CHGB experience opposing deregulation in the SALS motor cortex compared to the $\mathrm{AD}$ hippocampus, with ANXA2, ATP6V1A, EIF4A2, NSF, and all the metallothioneins detected in the hippocampus (MT1E, MT1G, $M T 1 X, M T 2 A)$ also showing markedly different regulation between both tissues.

\section{Discussion}

\section{A framework for the understanding of ALS pathogenesis}

A combination of candidate genes and pathway-based analysis provided a comprehensive view, at the level of mRNA, of the processes involved in ALS pathogenesis, suggesting an interpretation of changes in gene expression within a framework of deregulated pathways (Figure 7). It should be pointed out that, inherent to the analysis of end-stage diseased tissue, microarray analysis cannot distinguish between bona-fide up- and down-regulation of a gene and the selective survival and death, respectively, of cells highly expressing it. This ambiguity generally does not alter the interpretation of the role a given candidate gene with an established function might play in disease pathology. Moreover, selective cell death or survival appear unlikely explanations for the identification of candidate genes with two-fold changes of expression. However, this limitation needs to be borne in mind and will not be re-itterated in the course of the discussion. Nearly all candidate genes identified by this study may be actors 


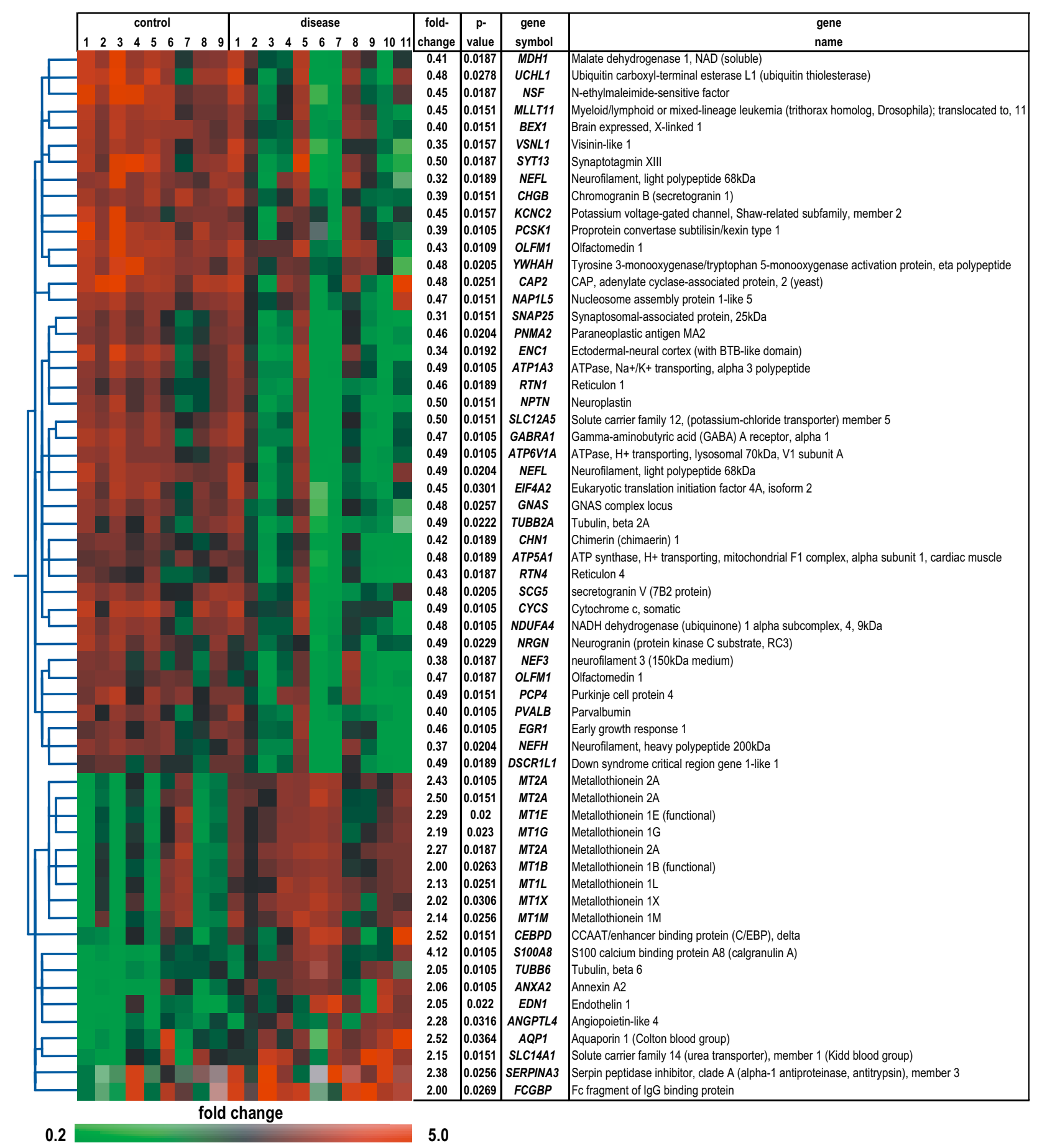

Figure 3

Genes differentially expressed in motor cortex of SALS subjects. 57 of $19,43 \mid$ quality-filtered genes $(0.3 \%)$, represented by $6 \mathrm{I}$ probes, are differentially expressed (corrected $P<0.05$ ), with each row in the matrix representing a single probe and each column a subject. Normalized expression levels are represented by the color of the corresponding cell, relative to the median abundance of each gene for each subject (see scale). Genes are named using their UniGene symbol and arranged in a hierarchical cluster (standard correlation) based on their expression patterns, combined with a dendrogram whose branch lengths reflect the relatedness of expression patterns. For each gene the fold-change (diseased vs. control) and corrected $P$ value are given. 


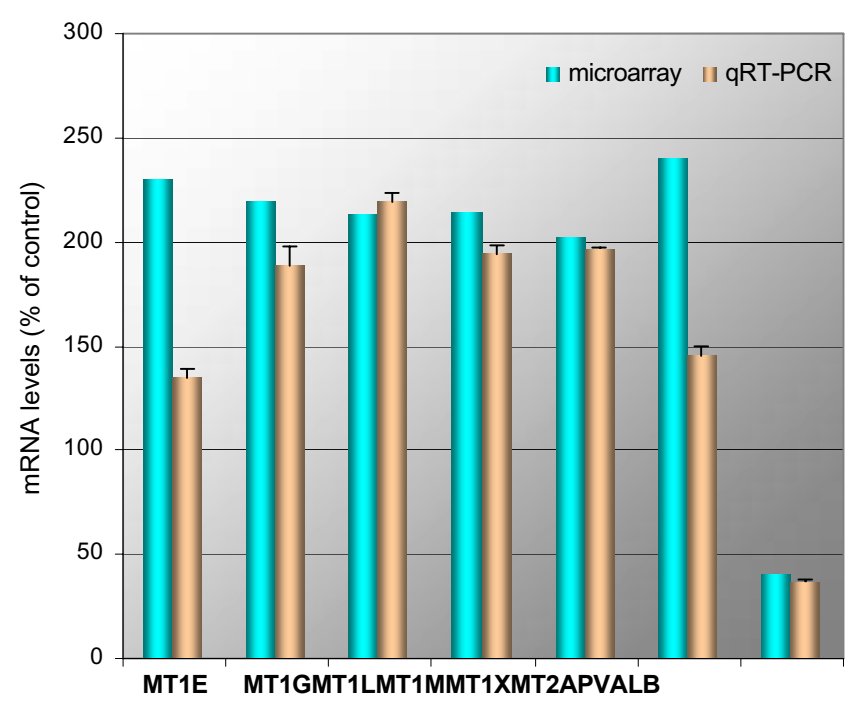

Figure 4

Comparison of microarray and $\mathrm{qRT}-\mathrm{PCR}$ results for selected candidate genes. The bar graph shows mean results of expression levels in SALS vs. control subject. Foldchanges are shown diseased vs. control, and differed by less than I.2-fold between qRT-PCR and microarray, except for MTIE and MT2A. Error bars for qRT-PCR data indicate the range for duplicate experiments. The $P$ values for $q R T-P C R$ and microarray (most significant probe) data were 0.342 and 0.020 (MTIE), 0.063 and 0.023 (MTIG), 0.037 and 0.025 (MTIL), 0.119 and 0.026 (MTIM), 0.074 and 0.03 I (MTIX), 0.063 and $0.01 \mathrm{I}$ (MT2A), and 0.037 and $0.01 \mathrm{I}$ (PVALB).

in ALS pathogenesis based on their existing characterizations, and some of them stand out as potentially critical to de-regulated processes and to ALS therapy.

\section{Mitochondrial energy metabolism}

Mitochondrial energy metabolism is a process down-regulated at the mRNA level and represented by all three major GO categories and by genes contributing to the tricarboxylic acid (TCA) cycle (MDH1) and involved in oxidative phosphorylation (CYCS, NDUFA4 and ATP5A1). The TCA accepts glycolysis-derived pyruvate as a key entry component. An alternative route for the supply of the TCA with pyruvate is its import downstream of the down-regulated MDH1, the cytosolic malate dehydrogenase [19]. Downstream of the TCA, oxidative phosphorylation occurs, for which we detected a specific down-regulation of genes encoding NDUFA4, a component of complex I of the electron transport chain in the inner mitochondrial membrane, CYCS, facilitating electron transport from complex III to complex IV in the intramembrane space, and ATP5A1, a component of the ATP synthase in the inner mitochondrial membrane. Importantly, the down-regulated CYCS is not only a component of mitochondrial oxidative phosphorylation, but also represents a cytoplasmic

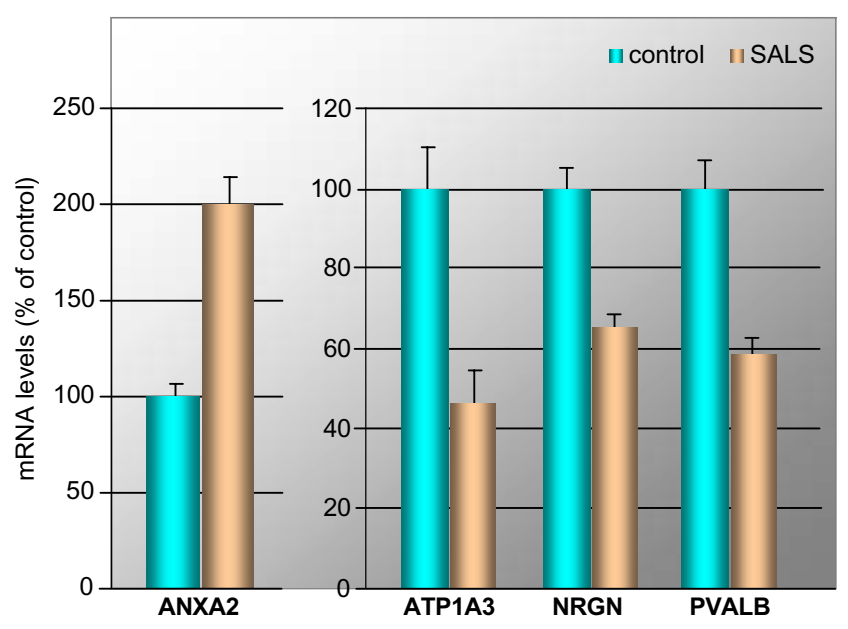

Figure 5

Changes of ANXA2, ATPIA3, NRGN, and PVALB mRNAs in motor cortex of SALS subjects. In-situ hybridization analysis of ANXA2, ATPIA3, NRGN, and PVALB mRNAs was performed in duplicate tissue sections of motor cortex from five control and five SALS subjects. Optical density values were normalized against those obtained in control subjects and subjected to two-tailed Student's t-test (with the $P$ values $3.44 \mathrm{e}-6$ (ANXA2), 7.9le-3 (ATPIA3), 2.29e-5 (NRGN) and 2.88e-6 (PVALB), respectively, diseased vs. control). The bar graph shows mean results and the standard deviation of the mean of labeling in control and SALS subjects.

signal for neuronal apoptosis as a result of impaired mitochondrial integrity. Opening of the mitochondrial transition pore normally serves the ion exchange between matrix and cytosol, but is thought to be exaggerated upon excitotoxic levels of $\mathrm{Ca}^{2+}$, leading to release of CYCS from the mitochondrion [20]. CYCS release, its activation of cellular caspases, and subsequent apoptosis have been proposed as a contributing factor to neuronal cell death in ALS [1]. A lowered expression of CYCS, however, would conceivably decrease the sensitivity to stress-induced apoptosis [21]. More significantly, our observations expand a role for mitochondrial dysfunction in the death of ALS motoneurons, which is otherwise mainly understood as a consequence of mitochondrial recruitment of mutant SOD1 in FALS [1], and which was even ruled out for SALS by one study [22]. Importantly, the significant down-regulation of GO nodes relating to mitochondria can not be the mere consequence of mitochondrial dysfunction or reduced numbers of mitochondria, as the GO hierarchy does not represent mitochondrion-encoded transcripts. Moreover, nuclear-encoded transcripts encoding mitochondrial proteins are universally induced during conditions of oxidative stress and mitochondrial damage [23], contrary to our observations for motor-cortical cells of SALS patients. 
A.

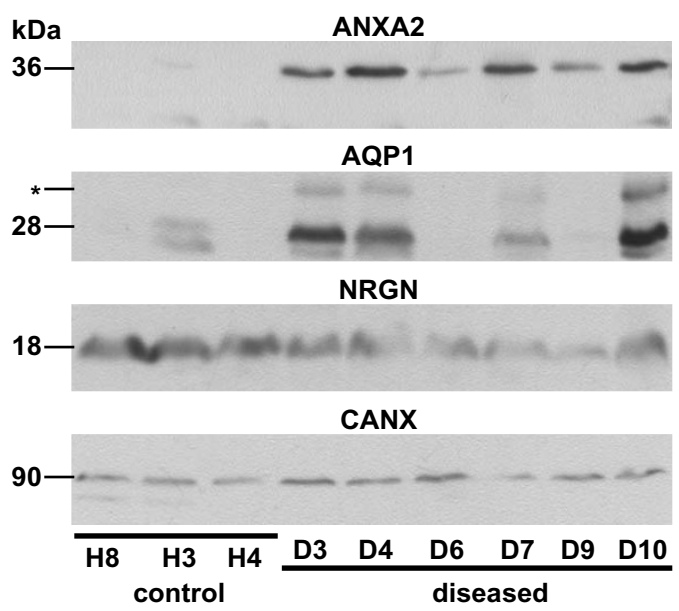

B.

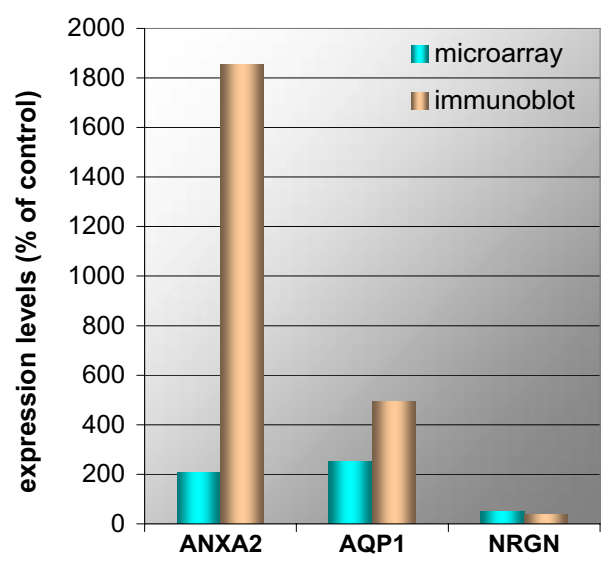

c.

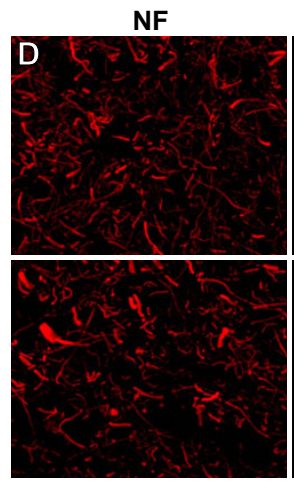

AQP1

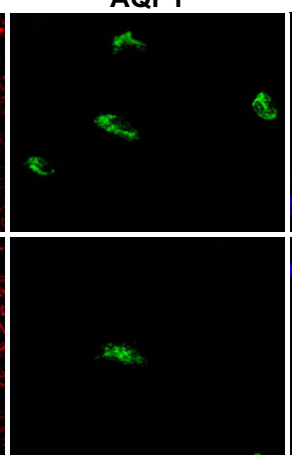

DNA

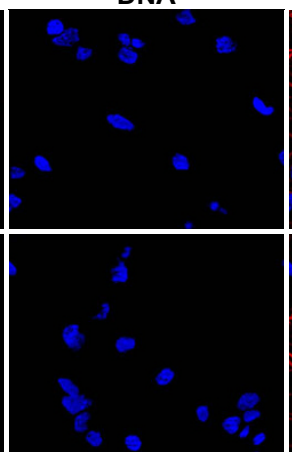

Overlay
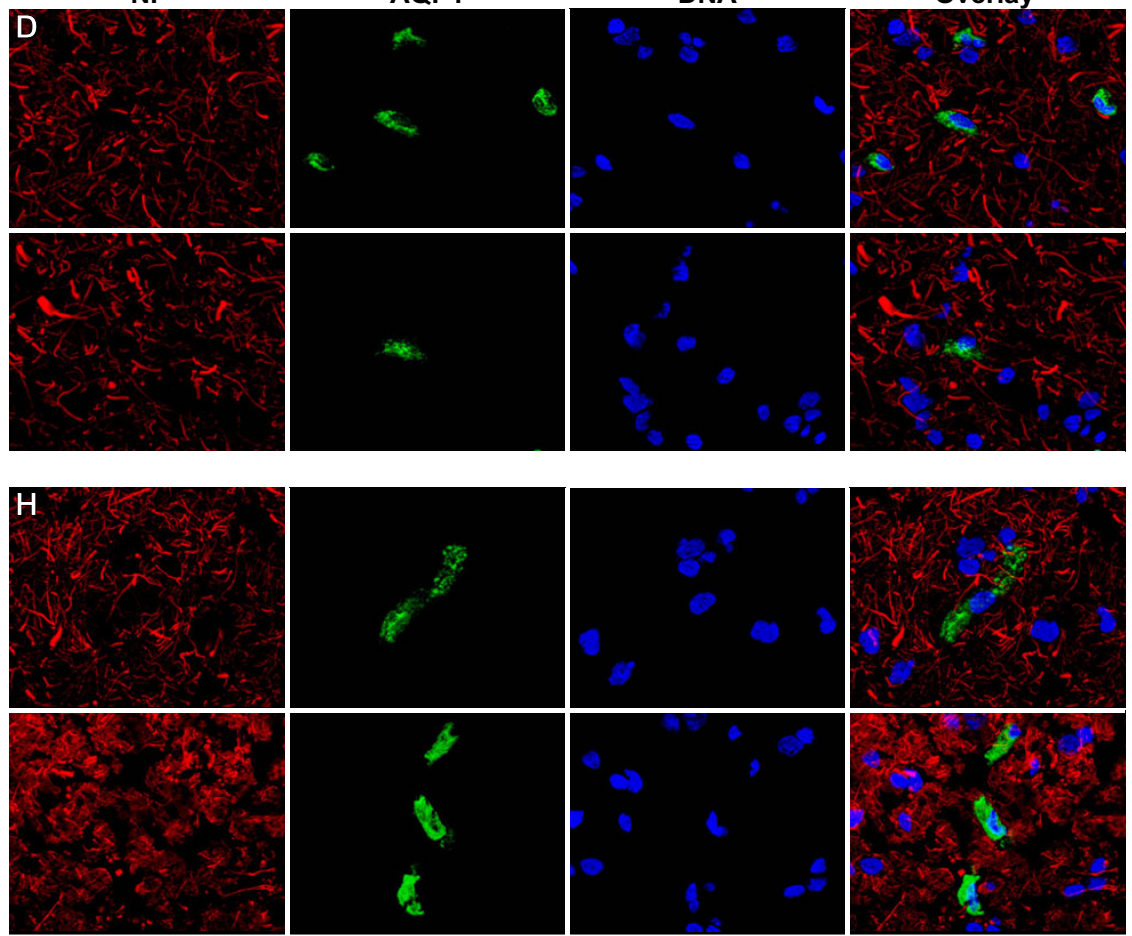

$100 \mu \mathrm{m}$

\section{Figure 6}

Immunodetection of selected candidate genes. (A) Immunoblots for ANXA2, AQPI, NRGN, and CANX was performed for three control and six diseased subjects. The size of quantified bands is indicated in $\mathrm{kDa}$. The glycosylated form of AQPI (*), undetectable in the healthy samples analyzed, was not included in the analysis. CANX served as a reference gene for sample normalization. (B) Bar graph comparing fold-changes of mean expression levels diseased vs. control as detected by immunoblot and microarray. Normalized intensity values are shown diseased vs. control and were analyzed by a two-tailed Student's t-test. $P$ values for immunoblot and microarray (most significant probe) data were 0.025 and 0.011 (ANXA2), 0.055 and $0.036(\mathrm{AQPI})$, and 0.047 and $0.023(\mathrm{NRGN})$, respectively). (C) Immunofluorescence detection of $A Q P I$ expression in non-neuronal cells in the diseased $(D)$ and the healthy $(H)$ motor cortex. NF - neurofilaments (red); AQPI - aquaporin I (green); DNA - Hoechst33342 counterstain (blue). The scale bar indicates $100 \mu \mathrm{m}$. 
Table 3: Comparison of expression ratios in motor cortex and spinal cord

\begin{tabular}{|c|c|c|c|c|}
\hline \multirow[b]{2}{*}{ Gene Symbol } & \multicolumn{4}{|c|}{ Expression Ratios } \\
\hline & UniGene ID & Motor Cortex & Spinal Cord & Comparison \\
\hline AQPI & Hs.76I52 & 2.52 & 2.84 & $==$ \\
\hline MT2A & Hs.4I824I & 2.43 & 4.66 & $=$ \\
\hline SLCI4AI & Hs. 101307 & 2.15 & 1.91 & $==$ \\
\hline ANXA2 & Hs.5II605 & 2.06 & 4.49 & $=$ \\
\hline MTIX & Hs.374950 & 2.02 & 1.99 & $==$ \\
\hline FCGBP & Hs.III 732 & 2.00 & 3.14 & $=$ \\
\hline DSCRILI & Hs. 440168 & 0.49 & 0.49 & $==$ \\
\hline PCP4 & Hs.80296 & 0.49 & 0.60 & $==$ \\
\hline SCG5 & Hs. 156540 & 0.48 & 0.58 & $==$ \\
\hline UCHLI & Hs.5।873I & 0.48 & 0.48 & $==$ \\
\hline GABRAI & Hs. 175934 & 0.47 & 0.56 & $==$ \\
\hline EGRI & Hs.326035 & 0.46 & 0.42 & $==$ \\
\hline OLFMI & Hs.522484 & 0.43 & 0.50 & $==$ \\
\hline VSNLI & Hs. 444212 & 0.35 & 0.38 & $==$ \\
\hline SNAP25 & Hs. 167317 & 0.31 & 0.82 & $<>$ \\
\hline $\mathrm{MDHI}$ & Hs.52652I & 0.41 & 0.68 & $<>$ \\
\hline $\mathrm{CHNI}$ & Hs.380I 38 & 0.42 & 0.71 & $<>$ \\
\hline EIF4A2 & Hs.478553 & 0.45 & 0.98 & $<>$ \\
\hline RTNI & Hs.368626 & 0.46 & 0.71 & $<>$ \\
\hline ATP5AI & Hs.298280 & 0.48 & 1.13 & $<>$ \\
\hline NDUFA4 & Hs.50098 & 0.48 & 0.73 & $<>$ \\
\hline PCSKI & Hs.78977 & 0.39 & 1.73 & $<>$ \\
\hline $\mathrm{CHGB}$ & Hs.5I6874 & 0.39 & 1.65 & $<>$ \\
\hline
\end{tabular}

Expression ratios for candidate genes identified in the present report (Motor Cortex) are compared to those found by Dangond et al. [4] (Spinal Cord), giving a correlation coefficient of $r=0.85$. Spinal cord data were retrieved from the Gene Expression Omnibus Database (GEO, series GSE833) and processed as described in the Methods section.

$==$ both tissues give the same result, differing $\leq 1.5$-fold

$=$ both tissues give the same result, differing $>1.5$-fold

$<>$ both tissues give different results (up- vs. down-regulation or deregulation vs. constancy, defining constancy as a $\leq 1.5$-fold deregulation)

\section{Glycolysis}

Glycolysis was detected as significantly down-regulated in the SALS motor cortex by pathway-based analysis of our microarray data. Glycolysis represents the cytoplasmic alternative to mitochondrial ATP generation by the TCA cycle and by oxidative phosphorylation, but is also a major source of pyruvate supply to the TCA cycle. At the level of individual genes, significant changes in gene expression similarly indicate a reduction of glycolysis (ANGPTL4) and glucose availability (CHGB, SCG5, PCSK1). The up-regulation of ANGPTL4 reduces expression of genes involved in glycolysis and gluconeogenesis [24]. The down-regulation of granins CHGB and SCG5, both processed by the down-regulated prohormone convertase PCSK1, increases insulin levels, hence reducing the availability of glucose for glycolysis [25]. In the context of ALS-related oxidative stress and neuronal modulation of ion gradients, a reduction of glycolytic energy supply, in combination with reduced mitochondrial energy supply, would constitute a major cause for neuronal cell death.

\section{Ion homeostasis and solute transport}

Ion homeostasis and solute transport is detected as reduced at the mRNA level by pathway-based analysis and covers both cytoplasmic and mitochondrial events (see Table 2). For instance, $71.7 \%$ of monovalent inorganic cation transporter activity includes genes involved in proton transport (hydrogen ion transporter activity, $\mathrm{z}=13.444, P=0$ ), commonly associated with organelle membranes (e.g. of mitochondria and lysosomes), and genes involved in the transport of sodium ions (sodium ion transporter activity, $\mathrm{z}$ $=10.059, P=0)$ and metal ions in general (metal ion transporter activity, $\mathrm{z}=8.147, P=0$ ), more commonly associated with the plasma membrane. Ion homeostasis and solute transport comprises three groups of candidate genes relating to excitotoxicity, calcium homeostasis, and water and solute transport, respectively.

Excitotoxicity, the excessive signaling of glutamate receptors, is a key pathogenic mechanism proposed in ALS, and is aggravated by a weakening of inhibitory synaptic events 
Table 4: Comparison of expression ratios in patients with SALS and Alzheimer's disease

\begin{tabular}{|c|c|c|c|c|}
\hline \multirow[b]{2}{*}{ Gene Symbol } & \multicolumn{4}{|c|}{ Expression Ratios } \\
\hline & UniGene ID & SALS & AD & Comparison \\
\hline AQPI & Hs.76I52 & 2.52 & 1.62 & $=$ \\
\hline CEBPD & Hs.440829 & 2.52 & 1.77 & $==$ \\
\hline SERPINA3 & Hs.534293 & 2.38 & 2.40 & $==$ \\
\hline SLCI4AI & Hs. 101307 & 2.15 & 2.20 & $==$ \\
\hline SLCI2A5 & Hs.2I4I3 & 0.50 & 0.40 & $==$ \\
\hline CYCS & Hs.437060 & 0.49 & 0.52 & $==$ \\
\hline DSCRILI & Hs. 440168 & 0.49 & 0.39 & $==$ \\
\hline NRGN & Hs.524II6 & 0.49 & 0.41 & $==$ \\
\hline PCP4 & Hs.80296 & 0.49 & 0.32 & $=$ \\
\hline ATP5AI & Hs.298280 & 0.48 & 0.61 & $==$ \\
\hline CAP2 & Hs. 132902 & 0.48 & 0.52 & $==$ \\
\hline GNAS & Hs. 125898 & 0.48 & 0.48 & $==$ \\
\hline NDUFA4 & Hs.50098 & 0.48 & 0.62 & $==$ \\
\hline UCHLI & Hs.5I873I & 0.48 & 0.67 & $==$ \\
\hline YWHAH & Hs.226755 & 0.48 & 0.53 & $==$ \\
\hline PNMA2 & Hs.52I 466 & 0.46 & 0.56 & $==$ \\
\hline RTNI & Hs.368626 & 0.46 & 0.37 & $==$ \\
\hline OLFMI & Hs.522484 & 0.43 & 0.55 & $==$ \\
\hline RTN4 & Hs.42958I & 0.43 & 0.75 & $=$ \\
\hline $\mathrm{CHNI}$ & Hs.380I38 & 0.42 & 0.50 & $==$ \\
\hline MDHI & Hs.52652I & 0.41 & 0.54 & $==$ \\
\hline BEXI & Hs.334370 & 0.40 & 0.63 & $=$ \\
\hline NEF3 & Hs.458657 & 0.38 & 0.28 & $==$ \\
\hline VSNLI & Hs. 444212 & 0.35 & 0.26 & $==$ \\
\hline $\mathrm{ENCl}$ & Hs. 104925 & 0.34 & 0.74 & $=$ \\
\hline NEFL & Hs.52I46I & 0.32 & 0.35 & $==$ \\
\hline SNAP25 & Hs. 167317 & 0.31 & 0.59 & $=$ \\
\hline MT2A & Hs.4I824I & 2.43 & 1.31 & $<>$ \\
\hline MTIE & Hs.534330 & 2.29 & 1.32 & $<>$ \\
\hline MTIG & Hs.43339I & 2.19 & 1.36 & $<>$ \\
\hline ANXA2 & Hs.5II 605 & 2.06 & 1.45 & $<>$ \\
\hline MTIX & Hs.374950 & 2.02 & 1.39 & $<>$ \\
\hline ATPIA3 & Hs.5I5427 & 0.49 & 1.46 & $<>$ \\
\hline ATP6VIA & Hs.477I55 & 0.49 & 0.78 & $<>$ \\
\hline EGRI & Hs.326035 & 0.46 & 1.63 & $<>$ \\
\hline EIF4A2 & Hs. 478553 & 0.45 & 0.75 & $<>$ \\
\hline NSF & Hs.43I 279 & 0.45 & 1.01 & $<>$ \\
\hline $\mathrm{CHGB}$ & Hs.5I 6874 & 0.39 & 2.37 & $<>$ \\
\hline
\end{tabular}

Expression ratios for candidate genes identified in the present report (SALS) are compared to those found for data by Blalock et al. [18] for Alzheimer's disease (AD), giving a correlation coefficient of $r=0.696$. AD data were retrieved from GEO (series GSEI297) and processed as described in the Methods section.

$==$ both tissues give the same result, differing $\leq 1.5$-fold

$=$ both tissues give the same result, differing $>1.5$-fold

$<>$ both tissues give different results (up- vs. down-regulation or deregulation vs. constancy, defining constancy as a $\leq 1.5$-fold deregulation)

mediated by the GABAA receptor. Alterations of its composition, such as the depletion of its GABRA1 subunit found in this study, was previously demonstrated in human motor cortex of ALS patients and is associated with heightened excitability [26]. Increased excitability, and hence exacerbated excitotoxicity, may also derive from the reduced expression of ATP1A3, KCNC2, and SLC12A5. Mutations of the plasma-membrane $\mathrm{Na}^{+} / \mathrm{K}^{+}$ pump ATP1A3 have been linked to rapid-onset dystonia- parkinsonism [27]. Moreover, ATP1A3 expression is reduced in SOD1(G93A) FALS mice [28] and in motoneurons of Wobbler mice, a genetic model of spinal-cord motoneuronal degeneration, with progesterone treatment restoring both, ATP1A3 mRNA expression and viability of motoneurons [29]. KCNC2 regulates the voltage-dependent potassium ion permeability of excitable membranes, and its decreased expression may lead to decreased potassium conductance and hence delayed repolarization of 


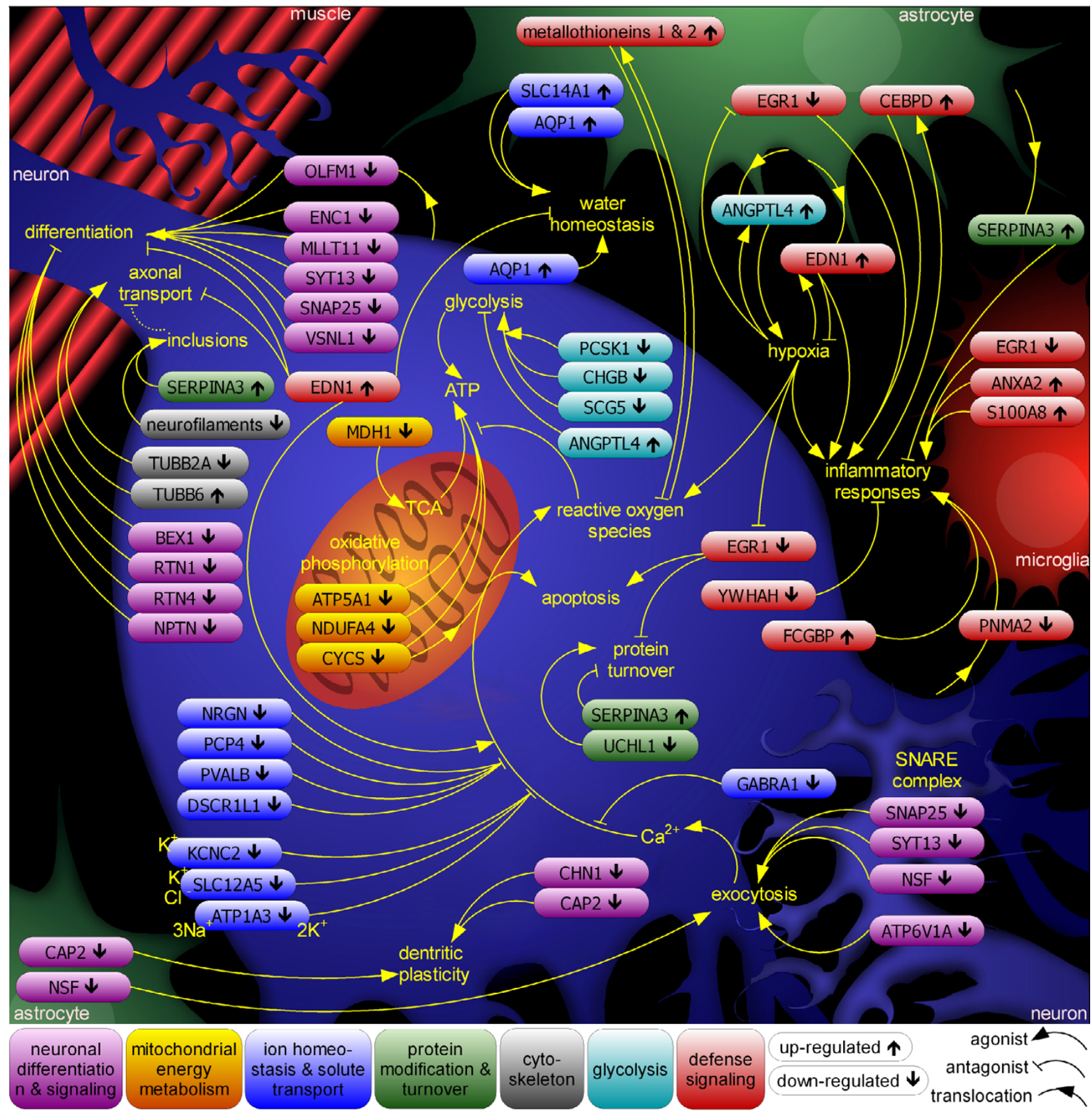

\section{Figure 7}

The interplay of cell types and pathways in SALS pathology. Combining pathways and candidate genes differentially expressed in the motor cortex of SALS patients reveals a complex interplay of cellular processes and cell types. Candidate genes corresponding to major pathways discussed in the main text are color-coded, placed in the cell type(s) where they most likely exert their influence, and their individual up- ( $\boldsymbol{N}$ ) or down-regulation $(\boldsymbol{w})$ is indicated. Genes EIF4A2, GNAS, and NAPIL5 are left out for clarity.

axons. While KCNC2 itself is poorly characterized, defects in other voltage-gated potassium channels can lead to hyperexcitability and hypersensitivity to oxidative stress [30]. SLC12A5 encodes the neuronal isoform of the potas- 
sium-chloride cotransporter family. During early development, increased expression of SLC12A5 lowers the intraneuronal chloride concentration below its electrochemical equilibrium and allows GABA to act as an inhibitory neurotransmitter. Conversely, a switch of GABA action from inhibitory to excitatory has been proposed as a mechanism contributing to excitotoxicity in injured neurons. Indeed, down-regulation of SLC12A5 expression together with GABAA receptor-mediated excitation occurs after in-vivo axonal injury [31], and mouse SLC12A5 knockouts suffer severe motor deficits and immediate postnatal death by asphyxiation [32].

Calcium homeostasis and calcium-binding proteins are critical to preventing motoneuron death in ALS, and with PVALB, DSCR1L1, NRGN, and PCP4 we found four genes down-regulated in the ALS motor cortex that moderate the impact of intracellular calcium release. There is disagreement whether the calcium buffer PVALB represents a marker of motoneurons resistant to ALS-related cell death $[33,34]$, but its reduction would likely increase cell death at the elevated calcium concentration typical of ALS [35]. Similarly, DSCR1L1 is an inhibitor of calcineurin [36], a mediator of many cellular responses, including apoptosis [37]. Depletion of the two calmodulin-binding proteins NRGN and PCP4, involved in moderating calmodulinmediated calcium signaling, would further reduce resistance to calcium-mediated toxicity $[38,39]$.

Water and solute transport is represented by the up-regulation of AQP1 and SLC14A1. Both, AQP1 and SLC14A1, experience up-regulation with age and by hypertonicity [40], and like AQP1 the urea transporter SLC14A1 may also function as an efficient water transporter [41]. Their joint up-regulation found in this study is indicative of disturbed ion and water homeostasis in the motor cortex of SALS patients. The water transporter AQP1 in particular is of interest through its association with synaptic vesicles and participation in their swelling in cells outside the central nervous system [42].

\section{Protein modification and turnover}

Protein modification and turnover are essential to motoneuron survival, resulting in the selective death of motoneurons upon chemical inhibition of the proteasome complex [43], which we detected as down-regulated in SALS samples by pathway-based analysis of our microarray data, thus stressing a role of disturbed protein turnover in ALS pathogenesis. Indeed, the progressive accumulation of polyubiquitinated protein conjugates, indicating a failure of proteasomal turnover, is a consistent feature of many neurodegenerative diseases [44], including ALS [1]. In line with this we also observed the down-regulation of UCHL1, a neuron-specific ubiquitin carboxy-terminal hydrolase-1, which also displays a sec- ondary dimerization-dependent ubiquitin-ligase activity and represents up to $2 \%$ of total soluble brain protein [45]. A point mutation affecting the ligase activity of UCHL1 has been linked to Parkinson's disease [46], while an internal 42-amino-acid deletion in UCHL1 is responsible for murine gracile axonal dystrophy, which is characterized by axonal degeneration and formation of spheroid bodies in nerve terminals [47]. The latter phenotype and the observation of poly-ubiquitinated aggregates in ALS create a tantalizing link between the hydrolase activity of UCHL1 and the depletion of UCHL1 mRNA in the motor cortex of SALS patients. Up-regulation of SERPINA3, a serine protease inhibitor enriched in neurofilament conglomerates of ALS motoneurons [48], can be seen in the same light and has been associated with other neurodegenerative diseases. In Alzheimer's disease, for instance, its astrocytic expression is elevated [49] and exacerbates the accumulation of protein aggregates [50]. SERPINA3 also has other effects, however, including protection against microglia [51].

\section{Cytoskeleton}

The cytoskeleton is critical for neuronal maintenance and plasticity, neurite outgrowth, axonal caliber and transport. Our analysis reveals the alteration of two major components of the neuronal cytoskeleton in the ALS motor cortex at the mRNA level, showing a general down-regulation of microtubules by pathway-based analysis and deregulation of two genes encoding tubulin beta (TUBB2A, TUBB6), as well as decreased expression of all three neurofilament subunits (NEFL, NEF3, NEFH). A depletion of microtubules and neurofilaments has deleterious effects on motoneurons, according to our present understanding of their role in ALS pathogenesis [1]. Impaired microtubule-based axonal transport causes related motoneuropathies and is the earliest detectable, presymptomatic abnormality in SOD1-mutant FALS mice. What is more, defects in microtubule-associated motor proteins cause ALS-related human motoneuropathies, such as Charcot-Marie-Tooth disease 2A [52] and hereditary spastic paraplegia [53], and are responsible for ALS phenotypes in Drosophila [54] and mouse [55]. The role of neurofilaments (NFs) in ALS is still controversial, despite a substantial body of research addressing the subject [1]. NF assemblies have been suggested as a possible impediment to axonal transport, either as its aberrantly crosslinked cargoes or in stationary aggregates, and even disturbing the stoichiometric balance between NF subunits can lead to ALS-like morphology and death of motoneurons. However, despite a raised incidence of mutations in NF genes in ALS subjects, a comprehensive study has excluded mutations in NF genes as a primary cause for ALS [56]. Moreover, ALS pathogenesis also progresses without axonal neurofilaments [57], and overexpression of NEFH prolongs survival of SOD1-transgenic 
FALS mice, prompting the hypothesis that NFs primarily act as an abundant buffer for otherwise deleterious processes, such as actions of SOD1 gain-of-function mutants [58] or aberrant tyrosine nitrosylation or phosphorylation $[1,59,60]$. The down-regulation of all three NF subunits observed in this study would be detrimental according to either interpretation of NF involvement in ALS pathology, first by interfering with their stoichiometric balance and second by depleting their availability as a potential buffer for aberrant enzymatic activities.

\section{Neuronal maintenance and signaling}

Changes in Neuronal maintenance and signaling, detected by gene-based analysis of our microarray data, comprise only down-regulated genes and tie in with observations for disturbed signaling in the motor cortex of sporadic, non-SOD1-linked ALS $[12,13]$. Depleted are general promoters of neurodifferentiation and axonal and dendritic maintenance (CAP2, ENC1, MLLT11, OLFM1, VSNL1), with clear implications for neuronal survival, but also several inhibitors of differentiation and promoters of cell proliferation (BEX1, CHN1, RTN1, RTN4, NPTN), whose role in ALS pathogenesis is ambiguous. Four additional genes (ATP6V1A, NSF, SNAP25, SYT13) encode proteins regulating synaptic vesicle processing and exocytosis, processes highly relevant to ALS pathology [1]. While most of the above genes are known to be expressed in multiple cell types, some of them (CHN1, NPTN, SNAP25, OLFM1, VSNL1) are neuron-specific. Importantly, we had ensured selecting patient material that exhibited good histological integrity of the motor cortex (see Figure 1), thus minimizing the possibility that observations for neuron-specific genes would reflect the loss of motoneurons typical of ALS.

MLLT11 expression is up-regulated in differentiated cortical neurons, and its ectopic expression in embryonic kidney cells triggers the expression of neuronal markers [61]. OLFM1, a secreted glycoprotein, is also strongly expressed in cerebral cortex $[62,63]$ and has been implicated in neural crest development in birds [64] and neurogenesis in Xenopus [65]. ENC1 is a matrix protein expressed almost exclusively in the brain, whose overexpression induces neuronal process formation and whose knock-down inhibits neurite development [66]. Similarly, the calciumdependent action of VSNL1 has been linked to the promotion of axonal differentiation and to axonal plasticity [67]. The multifunctional protein encoded by CAP2 links the actin cytoskeleton and CAMP signaling, and might therefore facilitate intracellular signal transduction events, dendritic plasticity and synaptic membrane recycling $[68,69]$.

Amongst the down-regulated inhibitors of neurodifferentiation in the SALS motor cortex are BEX1, a promoter of cell proliferation [70], and RTN1 and RTN4, two mem- bers of the reticulon family thought to play an important role in the regulation of neuronal regeneration. RTN4, in particular, is a potent neurite outgrowth inhibitor and has been shown to inhibit the regeneration of severed axons in the mammalian central nervous system [71]. NPTN encodes a protein involved in cell-cell interactions that inhibits neurite outgrowth from dorsal root ganglion and forebrain neurons [72]. Finally, CHN1 encodes the Rac GTPase activating protein alpha-1-chimerin, which mediates the pruning of dendrites in response to synaptic activity [73].

ATP6V1A is a subunit of the vacuolar proton pump VATPase, which generates a proton gradient across the membrane of maturing synaptic vesicles, required for the accumulation of neurotransmitters within them [74]. SNAP25 is a mediator of axonal repair, a regulator of calcium signaling, and a component of the NSF-binding SNARE complex, essential to vesicle fusion and recycling [75], and therefore has an impact on at least three processes critical to ALS pathogenesis. Like alsin, a likely regulator of endosome dynamics and a causative gene for juvenile forms of ALS [1], SNAP25 is also involved in endosome recycling [76], creating a fourth, albeit tentative, link of SNAP25 to ALS pathogenesis. SYT13, like SNAP25, participates in neurite outgrowth and axonal repair, and unlike usual synaptotagmins binds to cellular membranes in a $\mathrm{Ca}^{2+}$-independent fashion to facilitate membrane fusion and exocytosis [77]. It is unclear whether SYT13, like other synaptotagmins, does so by interaction with SNAP25. Following membrane fusions the down-regulated NSF, a key component of internal and exocytotic vesicle transport [78], facilitates the ATPdependent recycling of SNARE proteins, such as SNAP25.

\section{Defense signaling}

Defense signaling has been implicated in ALS pathogenesis by numerous studies showing inflammatory and immune responses [1], and linking the detection of IgG in ALS motoneurons to neuronal apoptosis [79]. Additional evidence is provided by the detection of IgG in motoneurons of the spinal cord and in pyramidal cells within the motor cortex of ALS patients [80-82] and by the ability of IgG from patients with ALS to induce apoptotic neuronal cell death $[79,83,84]$. Importantly, IgG purified from ALS patients was found to induce synaptic transmission through interaction with presynaptic membranes, relating autoantibodies in ALS to excitotoxicity [85]. In the present study defense signaling comprises the only up-regulated GO categories in the SALS motor cortex, and is represented by numerous candidate genes, whose differential expression likely promotes (FCGBP, YWHAH, ANXA2, S100A8, EDN1, CEBPD) or suppresses (EGR1, metallothioneins) inflammatory responses, respectively. Down-regulation of PNMA2, whose product is a target of 
neurodegenerative autoimmune responses, is reminiscent of a PNMA2-autoantibody-associated encephalitis patient with ALS symptoms, who presented with inflammation in cortex and spinal-cord grey matter $[86,87]$. With a suspected contribution of inflammatory responses to ALS pathogenesis, this suggests the targeting of PNMA2 by neurodegenerative autoimmune responses, leading to a depletion of PNMA2-positive cells. In line with this, the up-regulated FCGBP, encoding an IgG-Fc binding protein, may be involved in immune protection and inflammation [88], and shows elevated serum levels in patients with autoimmune disorders [89]. Elevated levels of FCGBP could therefore contribute to ALS pathogenesis by facilitating autoimmune and neuroinflammatory responses. Up-regulation of $C E B P D$, encoding a transcription factor of cytokines and other pro-inflammatory response genes, elevated in the brain of Alzheimer's disease patients and itself induced by inflammatory stimuli, ties in with this assumption [90]. Similarly, the down-regulation of $Y W H A H$, a gene linked to schizophrenia that encodes a transcriptional activator of the glucocorticoid receptor [91] and therefore of anti-inflammatory responses, can also be predicted to aggravate neuroinflammation. The up-regulated candidate genes ANXA2 and S100A8 encode two $\mathrm{Ca}^{2+}$-modulated proteins expressed in microglia and are implicated in the intracellular and extracellular regulation of inflammatory responses [92,93]. ANXA2 promotes generation of plasmin on the cell surface [94], a process linked to excitotoxin-induced neurodegeneration [95]. S100A8 mediates inflammatory responses, such as the induction of chemokines, and has been linked to the reduction of cell junction proteins and of membrane integrity [96].

The multifunctionality of EDN1 and EGR1 make the consequences of their differential expression in the SALS motor cortex ambiguous. For instance, the up-regulated $E D N 1$, encoding a pro-inflammatory vasoconstrictor peptide, exerts a variety of ALS-aggravating effects, including axonal degeneration [97], impairment of water homeostasis, heightened sensitivity to hypoxic stress [98], and increased excitotoxicity [99]. However, neuron-specific EDN1-knockout mice show elevated sensitivity to pain [100], and EDN1 expression in astrocytes is required for their survival under oxidative stress [101]. Moreover, the hypoxia-inducible EDN1 promotes angiogenesis, reducing the possible effects of hypoxia-related oxidative stress $[101,102]$, amongst other mechanisms by activation of the vascular endothelial growth factor. On the other hand, down-regulation of EGR1, a master switch of inflammatory responses prompted by oxidative stress [103], counteracts angiogenesis, thus increasing hypoxic conditions, but has an anti-inflammatory effect. It is important to note that the up-regulated ANGPTL4 (see Glycolysis above) and the down-regulated EGR1, two inducers of angiogenesis $[6,104]$, represent a positive and a negative target of the hypoxia-induced peroxisome-proliferatoractivated receptor gamma $[103,105]$, respectively. Therefore the differential expression of EGR1, ANGPTL4, and EDN1 indicates hypoxic conditions in the SALS motor cortex, tying in with a predisposition for ALS by mutation of angiogenin in man [106] and of vascular endothelial growth factor in mouse [107].

Indicating protective responses in the SALS motor cortex, we observed the up-regulation at the mRNA level of metallothioneins (MT1E, MT1G, MT1L, MT1M, MT1X, MT2A), neuroprotective, anti-oxidant stress-response proteins induced by metal ions, cytokines, and other stress stimuli [108]. Metallothioneins of the MT1 and MT2 families are expressed in astrocytes, and are increased in spinal cord of ALS patients and in transgenic mutant-SOD1 mice, where their experimental reduction significantly reduces survival. Importantly, endogenous MT1 and MT2 are undetectable in pure motoneuron cultures, which can be protected against oxidative stress by experimental MT1 overexpression [109], indicating the importance of metallothionein-mediated protection normally provided by astrocytes.

\section{Orphan genes}

Orphan genes, candidate genes with wide-ranging functions (EIF4A2) or without sufficient functional characterization (NAP1L5, GNAS), can only be associated tentatively with major deregulated pathways identified in this study, and were omitted from Figure 7. The down-regulated translation initiation factor EIF4A2 is interchangeable with EIF4A1 for the initiation of translation in general, and induces neural folding during embryonic development [110]. Interestingly, EIF4A2 has also been linked to type-2 diabetes and in rat cells appears to suppress insulin expression [111]. Its down-regulation, like that of CHGB, SCG5, and PCSK1, would therefore lead to elevated insulin levels and hence reduced glucose availability (see Glycolysis above). The down-regulated NAP1L5 is an imprinted and largely uncharacterized gene, highly expressed in brain [112]. NAP1L5 has sequence similarity to NAP1, a cytoplasmic-nuclear shuttle protein for histones, that has large-scale effects on gene expression by chromatin restructuring [113]. The GNAS gene is also down-regulated and, like NAP1L5, is imprinted [114]. Alternative first exons for GNAS transcripts lead to distinct products, which in human have been linked to osteodystrophy and pseudohypoparathyroidism phenotypes, while in mouse GNAS heterozygous mutants show metabolic abnormalities and insulin hypersensitivity (see Glycolysis above). 


\section{Conclusion Global reduction of energy supply}

Pathway-based and gene-based analyses show a general down-regulation of nuclear genes encoding mitochondrial components in the motor cortex of ALS patients. Although at first glance tying in with ALS-related mitochondrial dysfunction, this observation is at odds with the heightened level of oxidative stress typical of ALS. Numerous studies have characterized oxidative stress as a general inducer of nuclear genes that boost replication, maintenance and repair of mitochondria, as compensatory action for stress-related mitochondrial damage and death (see [23]). The down-regulation observed in the present study suggests alternative signaling to achieve a targeted depletion of mitochondrial components in the SALS motor cortex, which might therefore be a cause rather than a consequence of ALS pathology.

As for mitochondrial energy supply, pathway-based and gene-based analyses have independently indicated a reduction in glycolytic activity. Experimental inhibition of glycolysis in an FALS cell-culture model diminishes cell viability, suggesting that ALS-related mitochondrial dysfunction critically reduces cellular ATP supply [115], while hypoglycemia is a strong inducer of oxidative stress, even in the absence of such aggravating factors [116]. Now our results indicate that reduction in glycolytic energy supply is in itself a factor contributing to ALS pathology, suggesting as one overriding cause of ALSrelated neuronal cell death the depletion of intracellular ATP levels by a combined reduction of the TCA cycle, oxidative phosphorylation and glycolysis.

Reduced intracellular ATP levels lead to increased susceptibility to cell death upon oxidative [117] and excitotoxic [118] stress, and would be particularly detrimental to the survival of neurons, as the re-establishment of $\mathrm{Ca}^{2+}$ gradients and of general ion homeostasis following neuronal signaling is highly ATP-dependent. As an aggravating factor, coordinated $\mathrm{Ca}^{2+}$ signaling is facilitated in neurons by strategic positioning of mitochondria near endoplasmicreticulum $\mathrm{Ca}^{2+}$-release sites [20]. Therefore, reduced availability of ATP would lead to a downward spiral of an inability to remove intracellular $\mathrm{Ca}^{2+}, \mathrm{Ca}^{2+}$-induced mitochondrial production of reactive oxygen species, and additional depletion of mitochondrial ATP supply.

The importance of addressing all cell types in ALS therapy During our expression analysis of the motor cortex we identified several candidate genes, such as AQP1, CEBPD, SERPINA3, and the MT1 and MT2 family members, which are exclusively expressed in non-neuronal cells. Particularly in the analysis of excitotoxicity and defense signaling, involving astrocytes and microglia, and in the interplay of inflammatory versus anti-inflammatory and of cell-death versus cell-rescue responses, the importance of different cell types involved in ALS pathology becomes apparent. The survival of motoneurons is highly dependent on their cellular environment, which is to a large majority made up of non-neuronal cells [119]. Data on the interaction of neurons with glial cells in the context of ALS are still patchy, but there is a growing understanding that non-neuronal cells have a fundamental role to play in the pathogenesis of neurodegenerative diseases [119]. Our data indicate a general increase of microglial activity and immune responses, likely aggravating ALS disease symptoms. It is known, however, that the role of microglia in neuropathies extends beyond immune responses alone. Only recently, activated microglia have been recognized to hypersensitize sensory neurons, and their role in motoneuronal excitotoxicity still remains to be investigated [120]. Moreover, our data show mixed signals from astrocytes, comprising inflammatory and anti-inflammatory responses, which have to be evaluated on an individual basis and might be modulated to slow disease progression. Astrocytes might have significant impact on the excitotoxicity and the oxidative stress responses detected by our study, as they are in close interaction with motoneurons and neuronal synapses, and themselves express all the components required for $\mathrm{Ca}^{2+}$-responsive vesicular glutamate release [121,122].

\section{Perspectives for ALS therapy}

In the absence of effective treatments for ALS, the search for potential therapeutics continues. Like Riluzole, the only approved ALS treatment to date, the vast majority of drugs currently considered for clinical trials are based on animal models with SOD1-mutant background (85\% in a recent survey [123]). Only an estimated $2 \%$ of ALS cases, however, are linked to SOD1, and resulting treatments might therefore, similar to Riluzole, have limited value as general ALS therapies. However, several candidate compounds for ALS therapy [123] address aspects of SOD1 mutants, such as oxidative stress, impaired metal binding, and defects in protein folding, that we have also identified as affected in the motor cortex of sporadic, non-SOD1linked patients.

A successful general therapy of ALS will have to consider the interplay and individual roles of different pathways and cell types in pathogenesis. The comprehensive analysis described here provides a full molecular portrait of the changes occurring in the motor cortex of SALS patients and provides new leads for the development of effective ALS therapies. Indeed, for the manipulation of many of the genes and pathways implicated by this study, experimental or therapeutic drugs, not yet discussed in the context of ALS, are already available [124,125]. Moreover, our findings suggest that several drugs, currently used to treat unrelated diseases, might be of benefit to ALS patients. 
These include bosentan, an EDN1-receptor antagonist employed against diabetes and pulmonary hypertension [126]. The widely used anti-inflammatory drug ibuprofen is an antagonist of isoleucin- $1 \beta$ and of its downstream target SERPINA3 [127]. GABA antagonists such as zopiclone, used to treat insomnia, are of potential benefit to GABRA1-related excitotoxicity [128]. Significantly, symptom progression was stopped in a patient presenting with anti-PNMA2-related motoneuron degeneration by a combination of corticosteroids, intravenous immunoglobulin and antiepileptic drugs [86]. Similarly, and although it is clear from SOD1-linked FALS that all the alterations detected in ALS can have a common root and are therefore interrelated, therapy of ALS might also require combined medication to combat disease progression at multiple fronts. Many of the potential targets of this battle have been outlined by this study.

\section{Methods}

\section{Characteristics of subjects}

Two groups of patient samples, consisting of eleven SALS and nine control subjects, were used in this study. Freshfrozen samples of human motor cortex (precentral-gyrus sections) were obtained from the NICHD Brain and Tissue Bank for Developmental Disorders under contracts NO1-HD-4-3368 and NO1-HD-4-3383 and selected for post-mortem intervals (PMI) prior to freezing not exceeding 24 hours. Additionally, two patient samples were obtained as total RNA from a commercial source (Ambion, Inc.). All sample material is certified to have been obtained following international ethical guidelines and with prior consent from a fully informed donor or a member of the donor's family. All disease samples were cases of spontaneous ALS, with a mean patient age of 68.2 \pm 7.6 years. Control samples had a mean patient age of $68.7 \pm 11.0$ years and were selected for matching age and for causes of death unrelated to ALS or other neurological disorders. Detailed information related to source code, age, sex, race, and storage of patient samples is given in Table 1.

\section{Sample preparation}

Individual slices of $10 \mu \mathrm{m}$ were produced from tissue samples at $-20^{\circ} \mathrm{C}$ by a Leica CM1510S cryostat (Leica Microsystems) and stored at $-80^{\circ} \mathrm{C}$ until further processing. Two slices per sample were stained by hematoxylin/eosin staining (Bio Optica) and for Nissl substance (with a microfiltered solution of cresyl violet, Sigma), respectively, to assess integrity of cellular and tissue morphology. Individual slices were used for in-situ hybridization and immunofluorescence (see below). Ten adjacent slices per sample were pooled and used for RNA extraction with Trizol (Invitrogen) following the manufacturer's standard protocol, followed by confirmation of RNA integrity by agarose gel electrophoresis.

\section{Microarray processing and data extraction}

Complementary RNAs (cRNAs) labeled with Cy5-CTP (Perkin-Elmer) were synthesized from $1 \mu \mathrm{g}$ of total RNA of each sample using the Low RNA Input Fluorescent Linear Amplification Kit (Agilent Technologies) following the manufacturer's protocol. A reference cRNA, labeled with Cy3-CTP (Perkin-Elmer), was synthesized from $1 \mu \mathrm{g}$ of sample D2 RNA. Aliquots (750 ng) of Cy3 and Cy5 labeled cRNA targets were co-hybridized on Whole Human Genome Oligo Microarrays (Agilent Technologies). Microarray hybridization and washing were performed using reagents and instruments (hybridization chambers and rotating oven) as indicated by the manufacturer (Agilent Technologies).

Microarrays were scanned at $10-\mu \mathrm{m}$ resolution using a GenePix Personal 4100A microarray scanner and the GenePix Pro 6.0 acquisition and data-extraction software (Molecular Devices, Corp.). Raw data were processed and analyzed with Acuity 4.0 (Molecular Devices, Corp.) and GeneSpring 7.2 (Agilent Technologies). To remove unreliable data, all genes from all samples were filtered for quality to include only probe data fulfilling all of the following criteria: the spot had $<3 \%$ of saturated pixels at 635 and $532 \mathrm{~nm}$; the spot was not flagged "bad", "not found" or "absent"; the spot had relatively uniform intensity and uniform background ( $\operatorname{Rgn~R}^{2} 635 / 532>0.6$ ); the spot was detectable well above background (signal-to-noise ratios at 635 or $532 \mathrm{~nm}>3$ ). Filtering data by quality control criteria short-listed 19,431 genes as our complete data set for Lowess normalization and subsequent analyses, out of a total of 44,233 probes (including control and alignment probes) present on the microarrays. The microarray data have been deposited in the Gene Expression Omnibus (GEO) database [129] under accession no. GSE4595.

\section{Pathway-based microarray analysis}

To analyze the gene expression changes in the context of known biological pathways we used the Gene Map Annotator and Pathway Profiler (GenMAPP) 2.0 software package [130].

Input data for GenMAPP analysis were unique probe identifiers, corresponding UniGene cluster IDs, an average fold-change and an uncorrected $P$ value (Welch's ttest) diseased vs. control for all 19,431 short-listed genes of our complete data set. If a UniGene cluster ID was represented by multiple probes, the probe carrying the lowest (most significant) uncorrected $P$ value was used for pathway-based comparison with spinal-cord data [4] (see below). GenMAPP dynamically links gene-expression data to the gene ontology (GO) hierarchy of biological processes, cellular components and molecular functions [131]. For each of the GO categories in the hierarchy (nodes), and including all the genes in its child nodes, 
GenMAPP identifies genes that meet a user-defined criterion ( $\geq 1$.2-fold-change in our analysis, as recommended by [132] and [133]). From the total number of genes analyzed, the number of genes in a category and the corresponding numbers of genes meeting the queried criterion a $\mathrm{z}$ score is calculated, which indicates the non-randomness (for high, positive $\mathrm{z}$ scores) of the proportion of genes meeting the criterion. Additionally, a corrected $P$ value is calculated through permutation analysis $(2000$ permutations) of the data, followed by Westfall-Young adjustment for multiple hypothesis testing. Permutation analysis sets limits to the resolution of extremely significant events, so that the $P$ value for all events with an uncorrected $P<0.0005$ equals zero. Only nodes with positive $\mathrm{z}$ scores and a corrected $P<0.05$ were considered in our analysis, with a higher $z$ score indicating greater significance between nodes of identical $P$ value.

\section{Gene-based microarray analysis}

Of our quality-filtered data set of 19,431 genes, those with an average change greater than twofold were screened by a two-sided one-way ANOVA using Welch's t-test (with a Kolmogorov-Smirnov-test $P$ value of 0.38 or above indicating a normal distribution of tested values), followed by the Benjamini and Hochberg False Discovery Rate procedure as a multiple testing correction. Genes with a corrected $P$ value $<0.05$ were selected as differentially expressed candidate genes. All candidate probe sequences were tested against the NCBI nucleotide database (November 2005) by BLASTN to update their annotations and confirm the specificity of each probe.

\section{Quantitative RT-PCR}

Sample total RNA $(2 \mu \mathrm{g})$ was reverse transcribed with the Protoscript reverse transcription kit (New England Biolabs) using the $\mathrm{VN}(\mathrm{dT})_{23}$ primer as recommended by the manufacturer. As a standard for relative RNA quantification (Standard cDNA), ten equivalent reactions using 2 $\mu \mathrm{g}$ pooled RNA from healthy control samples (222 ng each) were performed and the resulting cDNAs precipitated and resuspended in $50 \mu \mathrm{l}$ water each. As a negative control for cDNA quantification, a further reaction using $2 \mu \mathrm{g}$ of pooled RNA was performed, in which the reverse transcriptase was replaced by water. All cDNAs were tested by conventional PCR with primers for glyceraldehyde-3phosphate dehydrogenase (New England Biolabs), using $1 / 50$ of each cDNA (the equivalent of 40 ng total RNA).

Quantitative RT-PCR (qRT-PCR) amplifications were performed with a LightCycler (Roche Molecular Biochemicals) using the same starting amount and LightCycler ${ }^{\circledast}$ FastStart DNA MasterPLUS SYBR Green I reagents in a standard volume of $20 \mu \mathrm{l}$. Real-time detection of fluorimetric intensity of SYBR Green I, indicating the amount of PCR product formed, was measured at the end of each elongation phase. Fluorescence values measured in the log-linear phase of amplification were considered using the second-derivative-maximum method of the LightCycler Data Analysis software (Roche Molecular Biochemicals). Relative quantification was performed using serial dilutions of pooled Standard CDNA (the equivalent of 80 , $40,20,10$ and 5 ng total RNA, respectively, run in duplicate) to provide a standard curve for each run. For all experiments, the standard curve had an error of below 5\% and extended over the relative quantities of all individual samples.

Candidate genes whose differential expression was tested by gene-specific qRT-PCR analysis were parvalbumin and the metallothioneins MT1B, MT1E, MT1G, MT1L, MT1M, MT1X and MT2A. Differences in the quantity of starting material were compensated by normalization with the housekeeping genes beta-2-microglobulin (B2M) and ribosomal protein L19 (RPL19). The primers used are detailed below. Normalized fold-changes between diseased and healthy samples were calculated and tested by a two-tailed Mann-Whitney U-test (not assuming equal variances).

\section{In-situ hybridization}

cDNAs corresponding to four mRNAs were synthesized by PCR from human brain RNA using specific forward and reverse primers. PCR fragments were subcloned into pCR4Blunt-TOPO vector (Invitrogen) and the orientation of the insert was determined by sequencing. Following linearization of plasmids by restriction endonucleases, riboprobes containing Cy3-CTP (sense) or Cy5-CTP (antisense) (Perkin-Elmer) were synthesized by T3 and T7 polymerase, respectively, using the MAXIscript In Vitro Transcription Kit (Ambion, Inc.). The in-situ hybridization procedure was performed as previously described [134]. Fluorescent hybridization signals were obtained by scanning sections at $5-\mu \mathrm{m}$ resolution using a GenePix Personal 4100A scanner (Molecular Devices, Corp.). No signal was detected in control brain sections hybridized with the sense riboprobes or pretreated with RNase before hybridization with the antisense probes. Evaluation of hybridization signals were obtained by using a computer-assisted image analysis system and the Photoshop 7.0 software (Adobe Systems, Inc.).

\section{Immunoblots}

Protein was extracted from human motor-cortex samples using standard methods. Following SDS-PAGE separation on $10-12 \%$ gels and semi-dry protein blotting (transfer buffer $10 \mathrm{mM} \mathrm{NaHCO}, 3 \mathrm{mM} \mathrm{Na}_{2} \mathrm{CO}_{3}, 20 \%$ methanol, $\mathrm{pH}$ 9.9) to nitrocellulose Hybond membranes (Amersham Pharmacia Biotech), blots were blocked $(0.1 \%$ Tween, 3\% milk PBS), incubated with the appropriate primary antibody at $4{ }^{\circ} \mathrm{C}$ over-night, and following three 
washes with PBS were incubated with secondary antibody. Primary antibodies (all Santa Cruz Biotechnology, Inc.) were rabbit antibodies ANXA2 (SC-9061), AQP1 (SC-20810), and CANX (SC-11397), and goat antibody NRGN (SC-18336), all at 1:100 dilution. As HRP-conjugated secondary antibodies (all Amersham Pharmacia Biotech) we applied a 1:4000 dilution of anti-rabbit antibody for detection of ANXA2, AQP1, and CANX, and of anti-goat antibody for NRGN. Immunoblots were visualized using the Enhanced Chemiluminescence System (Amersham Pharmacia Biotech). Band intensities were determined as background-corrected volume measurements using the ImageQuant TL software (Amersham Pharmacia Biotech), were equalized using CANX as a loading reference (which has not been linked to ALS and in our microarray analysis showed an mRNA ratio diseased vs. control of 0.97), and were subjected to statistical analysis using a two-tailed, heteroscedastic Student's t-test in Excel (Microsoft Corp.).

\section{Primers}

The following forward (FP) and reverse (RP) primers were used for qRT-PCR analysis: PVALB (GenBank Accession No: NM_002854, forward primer (FP): 5'-acgctgaggacatcaagaagg-3', 5'-caattttgccgtccccatc-3), reverse primer (RP): MT1B (GenBank Accession No.: NM 005947, FP1: 5'actccaggcttgtcttggctcc-3', RP1: 5'-tgggagcagggctctcccaa-3', FP2: 5'-ttgcctaggaactccaggcttgt-3', RP2: 5'-gcagcggcacttctctgatgag-3', FP3: 5'-tgctgctcttgctgccccgt-3', RP3: 5'-aaagaatgtagcaaaccggtcaggg-3'), MT1E (GenBank Accession No.: NM 175617, FP: 5'-ccttcttccccaggctgctgt-3', RP: 5'-aatgcagcaaatggctcagtgttg-3'), MT1G (GenBank Accession No.: BC035287, FP: 5'-gcatctgcaaaggggcatcg-3', RP: 5'-aaaggaatgtagcaaaggggtcaaga-3'), MT1L (GenBank Accession No.: BC070351, FP: 5'-gggctcctgctcctgtgcca-3', RP: 5'ggaatgtagcaaatgctcagggttg-3'), MT1M (GenBank Accession No.: NM 176870, FP: 5'-tggtgtctectgcgcctgca-3', RP: 5'-aatgcagcaaatggctcagtatcgtatt- $3^{\prime}$ ), MT1X (GenBank Accession No.: BC053882, FP: 5'-tgctgctcctgctgccetgt-3', RP: 5'-aaaagatgtagcaaacgggtcaggg-3'), MT2A (GenBank Accession No.: NM 005953, FP: 5'-cgactctagccgcctcttca-3', RP: 5'gaaaaaggaatatagcaaacggtcac-3'), RPL19 (GenBank Accession No.: NM 000981, FP: 5'-ggctgctcagaagataccgtg-3', RP: 5'-ggcgcttgcgtgcttccttg-3') and B2M (GenBank Accession No.: NM_004048, FP: 5'-agcgtactccaaagattcaggtt-3', RP: 5'-tacatgtctcgatcccacttaactat-3'). Specificity of PCR products obtained was characterized by melting-curve analysis followed by gel electrophoresis and DNA sequencing.

The following primers were used to amplify fragments for in-situ hybridization: ATP1A3 (GenBank Accession No.: NM 152296; FP: 5'-tcaagaaggaggtggctatg-3', RP: 5'gagaagcagccagtgatgat-3');NRGN (GenBank Accession No.: NM 006176; FP: 5'-gactaggccagaactgagca-3', RP: 5'-agt- ggcacggagatgtagg-3'); PVALB (GenBank Accession No.: NM 002854; FP: 5'-agttgcaggatgtcgatgac-3', RP: 5'-ccagagtggagaattcgtca-3'); ANXA2 (GenBank Accession No.: NM_004039; FP: 5'-gatcatctgctccagaacca-3', RP: 5'-gagtcatacagccgatcagc- $\left.3^{\prime}\right)$.

\section{Comparison with SALS spinal-cord and AD hippocampus expression data}

For SALS spinal-cord data, series GSE833 [4] of GEO was imported into Excel (Microsoft Corp.), and all UniGene ID numbers were updated (January 2006) using probe identities of the HuGeneFL array (Affymetrix, Inc.) in the NetAff ${ }^{\mathrm{TM}}$ Analysis Center (Affymetrix, Inc.). Fold-changes were calculated for five SALS samples (GSM6827, GSM6828, GSM6834, GSM6835, GSM6836) vs. four control samples (GSM6826, GSM6829, GSM6830, GSM6831), for genes with a corresponding UniGene ID and showing a signal level of $>100$ in at least five of these nine samples (3276 genes of a total of 7070 present on the HuGeneFL array). For 2266 of these genes the equivalent, quality-filtered (see above) non-redundant Agilent probes with the lowest uncorrected $P$ value (see GenMAPP analysis above) were short-listed to calculate a correlation coefficient $r$ for the expression ratios in spinal cord and motor cortex using Excel. A correlation coefficient was determined for all 2266 shared genes and for 23 shared genes corresponding to candidate genes identified in motor cortex by gene-based analysis, respectively.

For AD hippocampus data, an analogous procedure was followed, using seven severe-AD samples (GSM21203, GSM21206, GSM21207， GSM21208， GSM21212, GSM21213, GSM21229) vs. nine controls (GSM21215, GSM21217, GSM21218, GSM21219, GSM21220, GSM21221, GSM21226, GSM21231, GSM21232) of the GEO series GSE1297, and including genes showing a signal level of $>100$ in at least eight of these 16 samples, resulting in a shared dataset of 6375 reliably detectable genes. A correlation coefficient was determined for the expression ratios diseased vs. control for these shared genes and for 38 shared genes identified as differentially expressed in our SALS study, respectively.

\section{Immunofluorescence}

Tissue slices were submerged for 10 minutes in acetone at $-20^{\circ} \mathrm{C}$, followed by washes in phosphate-buffered saline (PBS), and incubation with $0.5 \%$ Triton in blocking solution $(2 \%$ fetal calf serum, $2 \%$ bovine serum albumin, $0.2 \%$ fish-skin gelatine) for 10 minutes. Tissue slices were then incubated with $10-\mathrm{mM}$ copper (II) sulfate and 50$\mathrm{mM}$ ammonium acetate ( $\mathrm{pH}$ 5.0) for $30 \mathrm{~min}$ to quench autofluorescence, followed by washes with PBS. Primary antibodies were co-incubated over-night at $4{ }^{\circ} \mathrm{C}$ at dilutions of 1:50 for AQP1 (AQP1 antibody H-55, Santa Cruz Biotechnology, Inc.) and 1:3000 for neurofilaments (200 
$\mathrm{kDa}+160 \mathrm{kDa}$ (phospho) antibody SMI 31, Abcam) in blocking solution without Triton X-100, followed by washes in PBS and co-incubation of secondary antibodies at room temperature at dilutions of 1:1500 anti-mouse Alexa Fluor 568 (A-11034, Molecular Probes) and 1:500 anti-rabbit Alexa Fluor 488 (A-21124, Molecular Probes). Tissue sections were then washed in PBS, incubated with Hoechst33342 as a DNA counter stain, washed in PBS, briefly air-dried, and mounted for microscopy in 10\% Mowiol, 1\% 1,4-Diazabicyclo [2.2.2] octane, and 25\% glycerol in 0.1-M Tris buffer ( $\mathrm{pH} 8$ ). Images were acquired using an Axiovert $200 \mathrm{M}$ microscope with the AxioVision 4.5 image acquisition software, the Apotome module and the transparency projection option for $\mathrm{Z}$ stacks of the Inside4D visualization module (all Carl Zeiss Inc.).

\section{Abbreviations}

For Unigene cluster IDs of candidate genes see Figure 3, conforming to the HUGO Gene Nomenclature Committee (HGNC) database (see [135]). All abbreviations are defined at their first appearance in the text, and in the legends of tables and figures, as follows:

$$
\begin{aligned}
& \text { AD - Alzheimer's disease } \\
& \text { ALS - amyotrophic lateral sclerosis } \\
& \text { BP - biological process } \\
& \text { CC - cellular component } \\
& \text { EGL - external granular layer } \\
& \text { EPL - external pyramidal layer } \\
& \text { FALS - familial ALS } \\
& \text { FP - forward primer } \\
& \text { GO - gene ontology } \\
& \text { IGL - internal granular layer } \\
& \text { IPL - internal pyramidal layer } \\
& \text { LMN - lower motoneuron } \\
& \text { NF - neurofilament } \\
& \text { MFL - molecular function }
\end{aligned}
$$

$\mathrm{RP}$ - reverse primer

qRT-PCR - quantitative reverse-transcriptase PCR

SALS - sporadic ALS

TCA - tricarboxylic acid cycle

UMN - upper motoneuron

\section{Authors' contributions}

CWL participated in the design of the study, carried out microarray experiments, their pathway-based statistical analysis and comparisons with publicly available microarray data, participated in gene-based statistical analyses, performed qRT-PCR analyses, immunofluorescence experiments and statistical analysis of immunoblot data, and drafted the manuscript. AT performed in-situ hybridization experiments. MP performed immunoblots. NS conceived of the study, participated in its design and coordination, and helped to draft the manuscript. SC designed the study, participated in its coordination, performed gene-based statistical analysis of microarray data, statistical analysis of in-situ hybridization data, and made major contributions to the manuscript. All authors have read and approved the final manuscript.

\section{Acknowledgements}

We thank Alfia Corsino, Maria Patrizia D'Angelo and Francesco Marino for administrative and technical support, and Kleopas Kleopa for discussions. This research was supported by grants from the Ministry of Health and the Ministry of Education, University and Research (Italy) (S.C.), and from the A.G. Leventis Foundation (France) and Telethon Foundation (Cyprus) (N.S.).

\section{References}

I. Shaw PJ: Molecular and cellular pathways of neurodegeneration in motor neurone disease. J Neurol Neurosurg Psychiatry 2005, 76: $1046-1057$.

2. Malaspina A, Kaushik N, de Belleroche J: Differential expression of I4 genes in amyotrophic lateral sclerosis spinal cord detected using gridded cDNA arrays. J Neurochem 200I, 77: $132-145$

3. liang YM, Yamamoto M, Kobayashi Y, Yoshihara T, Liang Y, Terao S, Takeuchi H, Ishigaki S, Katsuno M, Adachi H, Niwa J, Tanaka F, Doyu M, Yoshida M, Hashizume Y, Sobue G: Gene expression profile of spinal motor neurons in sporadic amyotrophic lateral sclerosis. Ann Neurol 2005, 57:236-25I.

4. Dangond F, Hwang D, Camelo S, Pasinelli P, Frosch MP, Stephanopoulos G, Stephanopoulos G, Brown RH Jr., Gullans SR: Molecular signature of late-stage human ALS revealed by expression profiling of postmortem spinal cord gray matter. Physiol Genomics 2004, 16:229-239.

5. Leigh PN, Abrahams S, Al Chalabi A, Ampong MA, Goldstein LH, Johnson J, Lyall R, Moxham J, Mustfa N, Rio A, Shaw C, Willey E: The management of motor neurone disease. J Neurol Neurosurg Psychiatry 2003, 74 Suppl 4:iv32-iv47.

6. Ince PG, Evans J, Knopp M, Forster G, Hamdalla HH, Wharton SB, Shaw PJ: Corticospinal tract degeneration in the progressive muscular atrophy variant of ALS. Neurology 2003, 60: $1252-1258$.

7. RM BV, Visser J, Franssen $H$, de Visser M, de Jong JM, Kalmijn S, Wokke JH, van den Berg LH: Sporadic lower motor neuron dis- 
ease with adult onset: classification of subtypes. Brain 2003 , 1 26: 1036-1047.

8. Wang S, Poptani H, Bilello M, Wu X, Woo JH, Elman LB, McCluskey LF, Krejza J, Melhem ER: Diffusion tensor imaging in amyotrophic lateral sclerosis: volumetric analysis of the corticospinal tract. AJNR Am J Neuroradiol 2006, 27: I 234-I238.

9. Kaufmann P, Pullman SL, Shungu DC, Chan S, Hays AP, Del Bene ML, Dover MA, Vukic M, Rowland LP, Mitsumoto H: Objective tests for upper motor neuron involvement in amyotrophic lateral sclerosis (ALS). Neurology 2004, 62: 1753-1757.

10. Sach M, Winkler G, Glauche V, Liepert J, Heimbach B, Koch MA, Buchel C, Weiller C: Diffusion tensor MRI of early upper motor neuron involvement in amyotrophic lateral sclerosis. Brain 2004, 1 27:340-350.

II. Martin JH: The corticospinal system: from development to motor control. Neuroscientist 2005, I I:161-173.

12. Turner MR, Osei-Lah AD, Hammers A, Al Chalabi A, Shaw CE Andersen PM, Brooks DJ, Leigh PN, Mills KR: Abnormal cortical excitability in sporadic but not homozygous D90A SODI ALS. J Neurol Neurosurg Psychiatry 2005, 76: | 279-1285.

13. Turner MR, Hammers A, Al Chalabi A, Shaw CE, Andersen PM, Brooks DJ, Leigh PN: Distinct cerebral lesions in sporadic and 'D90A' SODI ALS: studies with [I IC]flumazenil PET. Brain 2005, I 28: 1323-1329.

14. Cudkowicz ME, McKenna-Yasek D, Chen C, Hedley-Whyte ET, Brown RH Jr.: Limited corticospinal tract involvement in amyotrophic lateral sclerosis subjects with the A4V mutation in the copper/zinc superoxide dismutase gene. Ann Neurol 1998, 43:703-7I0.

15. Tian Q, Stepaniants SB, Mao M, Weng L, Feetham MC, Doyle MJ, Yi EC, Dai H, Thorsson V, Eng J, Goodlett D, Berger JP, Gunter B, Linseley PS, Stoughton RB, Aebersold R, Collins SJ, Hanlon WA, Hood LE: Integrated genomic and proteomic analyses of gene expression in Mammalian cells. Mol Cell Proteomics 2004, 3:960-969.

16. Badaut J, Lasbennes F, Magistretti PJ, Regli L: Aquaporins in brain: distribution, physiology, and pathophysiology. I Cereb Blood Flow Metab 2002, 22:367-378.

17. Gao H, He C, Fang X, Hou X, Feng X, Yang H, Zhao X, Ma T: Localization of aquaporin-I water channel in glial cells of the human peripheral nervous system. Glia 2006, 53:783-787.

18. Blalock EM, Geddes JW, Chen KC, Porter NM, Markesbery WR, Landfield PW: Incipient Alzheimer's disease: microarray correlation analyses reveal major transcriptional and tumor suppressor responses. Proc Natl Acad Sci U S A 2004, I0I:2173-2178.

19. MacDonald MJ, Fahien LA, Brown LJ, Hasan NM, Buss JD, Kendrick MA: Perspective: emerging evidence for signaling roles of mitochondrial anaplerotic products in insulin secretion. Am J Physiol Endocrinol Metab 2005, 288:EI-I5.

20. Brookes PS, Yoon Y, Robotham JL, Anders MW, Sheu SS: Calcium ATP, and ROS: a mitochondrial love-hate triangle. Am J Physiol Cell Physiol 2004, 287:C8I7-C833.

21. Li K, Li Y, Shelton JM, Richardson JA, Spencer E, Chen ZJ, Wang X, Williams RS: Cytochrome c deficiency causes embryonic lethality and attenuates stress-induced apoptosis. Cell 2000, I 01:389-399.

22. Browne SE, Bowling AC, Baik MJ, Gurney M, Brown RH Jr., Beal MF: Metabolic dysfunction in familial, but not sporadic, amyotrophic lateral sclerosis. J Neurochem 1998, 71:28I-287.

23. Lee HC, Wei YH: Mitochondrial biogenesis and mitochondrial DNA maintenance of mammalian cells under oxidative stress. Int J Biochem Cell Biol 2005, 37:822-834.

24. Xu A, Lam MC, Chan KW, Wang Y, Zhang J, Hoo RL, Xu JY, Chen B, Chow WS, Tso AW, Lam KS: Angiopoietin-like protein 4 decreases blood glucose and improves glucose tolerance but induces hyperlipidemia and hepatic steatosis in mice. Proc Natl Acad Sci U S A 2005, 102:6086-6091.

25. Taupenot L, Harper KL, O'Connor DT: The chromogranin-secretogranin family. N Engl | Med 2003, 348: | |34- | | 49.

26. Petri S, Krampfl K, Hashemi F, Grothe C, Hori A, Dengler R, Bufler J: Distribution of GABAA receptor $m R N A$ in the motor cortex of ALS patients. J Neuropathol Exp Neurol 2003, 62:104I-I05I.

27. de Carvalho AP, Sweadner KJ, Penniston JT, Zaremba J, Liu L, Caton M, Linazasoro G, Borg M, Tijssen MA, Bressman SB, Dobyns WB, Brashear A, Ozelius LJ: Mutations in the $\mathbf{N a + / K +}$-ATPase alpha3 gene ATPIA3 are associated with rapid-onset dystonia parkinsonism. Neuron 2004, 43:169-I75.

28. Ellis DZ, Rabe J, Sweadner KJ: Global loss of Na,K-ATPase and its nitric oxide-mediated regulation in a transgenic mouse model of amyotrophic lateral sclerosis. J Neurosci 2003, 23:43-5I.

29. Gonzalez Deniselle MC, Lopez-Costa J], Saavedra JP, Pietranera L, Gonzalez SL, Garay L, Guennoun R, Schumacher M, De Nicola AF: Progesterone neuroprotection in the Wobbler mouse, a genetic model of spinal cord motor neuron disease. Neurobiol Dis 2002, II:457-468.

30. Wang JW, Humphreys JM, Phillips JP, Hilliker AJ, Wu CF: A novel leg-shaking Drosophila mutant defective in a voltage-gated $K(+)$ current and hypersensitive to reactive oxygen species. Neurosci 2000, 20:5958-5964.

31. Nabekura J, Ueno T, Okabe A, Furuta A, Iwaki T, Shimizu-Okabe C, Fukuda $A$, Akaike N: Reduction of KCC2 expression and GABAA receptor-mediated excitation after in vivo axonal injury. J Neurosci 2002, 22:44I2-44I7.

32. Hubner CA, Stein V, Hermans-Borgmeyer I, Meyer T, Ballanyi K, Jentsch TJ: Disruption of $\mathrm{KCC2}$ reveals an essential role of $\mathrm{K}-\mathrm{Cl}$ cotransport already in early synaptic inhibition. Neuron 200I, 30:5I5-524.

33. Elliott JL, Snider WD: Parvalbumin is a marker of ALS-resistant motor neurons. Neuroreport 1995, 6:449-452.

34. Laslo P, Lipski J, Nicholson LF, Miles GB, Funk GD: Calcium binding proteins in motoneurons at low and high risk for degeneration in ALS. Neuroreport 2000, I I:3305-3308.

35. Appel SH, Beers D, Siklos L, Engelhardt JI, Mosier DR: Calcium: the Darth Vader of ALS. Amyotroph Lateral Scler Other Motor Neuron Disord 200I, 2 Suppl I:S47-S54.

36. Cao X, Kambe F, Miyazaki T, Sarkar D, Ohmori S, Seo H: Novel human ZAKI-4 isoforms: hormonal and tissue-specific regulation and function as calcineurin inhibitors. Biochem / 2002, 367:459-466

37. Asai A, Qiu J, Narita Y, Chi S, Saito N, Shinoura N, Hamada H, Kuchino $Y$, Kirino T: High level calcineurin activity predisposes neuronal cells to apoptosis. J Biol Chem 1999, 274:34450-34458.

38. Slemmon JR, Feng B, Erhardt JA: Small proteins that modulate calmodulin-dependent signal transduction: effects of PEP19 , neuromodulin, and neurogranin on enzyme activation and cellular homeostasis. Mol Neurobiol 2000, 22:99-I I3.

39. Putkey JA, Kleerekoper Q, Gaertner TR, Waxham MN: A new role for IQ motif proteins in regulating calmodulin function. J Biol Chem 2003, 278:49667-49670.

40. Trinh-Trang-Tan MM, Geelen G, Teillet L, Corman B: Urea transporter expression in aging kidney and brain during dehydration. Am J Physiol Regul Integr Comp Physiol 2003, 285:R I355-R I365.

41. Shayakul C, Hediger MA: The SLCI 4 gene family of urea transporters. Pflugers Arch 2004, 447:603-609.

42. Jeremic A, Cho WJ, Jena BP: Involvement of water channels in synaptic vesicle swelling. Exp Biol Med (Maywood) 2005, 230:674-680

43. Tsuji S, Kikuchi S, Shinpo K, Tashiro J, Kishimoto R, Yabe I, Yamagishi $\mathrm{S}$, Takeuchi M, Sasaki H: Proteasome inhibition induces selective motor neuron death in organotypic slice cultures. J Neurosci Res 2005, 82:443-45।.

44. Wolozin B, Behl C: Mechanisms of neurodegenerative disorders: Part I: protein aggregates. Arch Neurol 2000, 57:793-796.

45. Bohlen und HO, Schober A, Krieglstein K: Genes, proteins, and neurotoxins involved in Parkinson's disease. Prog Neurobiol 2004, 73:15I-177.

46. Liu Y, Fallon L, Lashuel HA, Liu Z, Lansbury PT Jr.: The UCH-LI gene encodes two opposing enzymatic activities that affect alpha-synuclein degradation and Parkinson's disease susceptibility. Cell 2002, I II:209-2I8.

47. Saigoh K, Wang YL, Suh JG, Yamanishi T, Sakai Y, Kiyosawa H, Harada T, Ichihara N, Wakana S, Kikuchi T, Wada K: Intragenic deletion in the gene encoding ubiquitin carboxy-terminal hydrolase in gad mice. Nat Genet 1999, 23:47-5I.

48. Chou SM, Taniguchi A, Wang HS, Festoff BW: Serpin=serine protease-like complexes within neurofilament conglomerates of motoneurons in amyotrophic lateral sclerosis. I Neurol Sci 1998, 160 SuppI I:S73-S79. 
49. Pasternack JM, Abraham CR, Van Dyke BJ, Potter H, Younkin SG Astrocytes in Alzheimer's disease gray matter express alpha I-antichymotrypsin mRNA. Am J Pathol 1989, I 35:827-834.

50. Nilsson LN, Arendash GW, Leighty RE, Costa DA, Low MA, Garcia MF, Cracciolo JR, Rojiani A, Wu X, Bales KR, Paul SM, Potter H: Cognitive impairment in PDAPP mice depends on ApoE and ACT-catalyzed amyloid formation. Neurobiol Aging 2004, 25: II53-I I67

5I. Klegeris A, McGeer PL: Chymotrypsin-like proteases contribute to human monocytic THP-I cell as well as human microglial neurotoxicity. Glia 2005, 5 I:56-64

52. Zhao C, Takita J, Tanaka Y, Setou M, Nakagawa T, Takeda S, Yang HW, Terada S, Nakata T, Takei Y, Saito M, Tsuji S, Hayashi Y, Hirokawa N: Charcot-Marie-Tooth disease type 2A caused by mutation in a microtubule motor KIFIBbeta. Cell 200I, I 05:587-597.

53. Reid E, Kloos M, shley-Koch A, Hughes L, Bevan S, Svenson IK, Graham FL, Gaskell PC, Dearlove A, Pericak-Vance MA, Rubinsztein DC, Marchuk DA: A kinesin heavy chain (KIF5A) mutation in hereditary spastic paraplegia (SPG I0). Am J Hum Genet 2002, 7I:II89-II94.

54. Hurd DD, Saxton WM: Kinesin mutations cause motor neuron disease phenotypes by disrupting fast axonal transport in Drosophila. Genetics 1996, I44:1075-1085

55. LaMonte BH, Wallace KE, Holloway BA, Shelly SS, Ascano J, Tokito M, Van WT, Howland DS, Holzbaur EL: Disruption of dynein/dynactin inhibits axonal transport in motor neurons causing late-onset progressive degeneration. Neuron 2002, 34:71 5-727.

56. Garcia ML, Singleton AB, Hernandez D, Ward CM, Evey C, Sapp PA Hardy J, Brown RH Jr., Cleveland DW: Mutations in neurofilament genes are not a significant primary cause of non-SOD I mediated amyotrophic lateral sclerosis. Neurobiol Dis 2006, 21: 102-109.

57. Eyer J, Cleveland DW, Wong PC, Peterson AC: Pathogenesis of two axonopathies does not require axonal neurofilaments. Nature 1998, 39 1:584-587.

58. Rowland LP, Shneider NA: Amyotrophic lateral sclerosis. N Engl J Med 2001, 344: I688-1700.

59. Bruijn LI, Beal MF, Becher MW, Schulz JB, Wong PC, Price DL, Cleveland DW: Elevated free nitrotyrosine levels, but not proteinbound nitrotyrosine or hydroxyl radicals, throughout amyotrophic lateral sclerosis (ALS)-like disease implicate tyrosine nitration as an aberrant in vivo property of one familial ALS linked superoxide dismutase I mutant. Proc Natl Acad Sci U S A | 997, 94:7606-76| |

60. Julien JP, Beaulieu JM: Cytoskeletal abnormalities in amyotrophic lateral sclerosis: beneficial or detrimental effects? Neurol Sci 2000, 180:7-14

6I. Lin HJ, Shaffer KM, Sun Z, Jay G, He WW, Ma W: AFIq, a differentially expressed gene during neuronal differentiation, transforms HEK cells into neuron-like cells. Brain Res Mol Brain Res 2004, I 3 | : | 26- I30.

62. Danielson PE, Forss-Petter S, Battenberg EL, deLecea L, Bloom FE, Sutcliffe JG: Four structurally distinct neuron-specific olfactomedin-related glycoproteins produced by differential promoter utilization and alternative mRNA splicing from a single gene. J Neurosci Res 1994, 38:468-478.

63. Nagano T, Nakamura A, Mori Y, Maeda M, Takami T, Shiosaka S, Takagi $H$, Sato $M$ : Differentially expressed olfactomedin-related glycoproteins (Pancortins) in the brain. Brain Res Mol Brain Res 1998, 53:13-23.

64. Barembaum M, Moreno TA, LaBonne C, Sechrist J, Bronner-Fraser M: Noelin-I is a secreted glycoprotein involved in generation of the neural crest. Nat Cell Biol 2000, 2:219-225.

65. Moreno TA, Bronner-Fraser M: The secreted glycoprotein Noelin-I promotes neurogenesis in Xenopus. Dev Biol 200I, 240:340-360.

66. Kim TA, Lim J, Ota S, Raja S, Rogers R, Rivnay B, Avraham H, Avraham S: NRP/B, a novel nuclear matrix protein, associates with pI I O(RB) and is involved in neuronal differentiation. J Cell Bio 1998, I 41:553-566.

67. Brackmann M, Schuchmann S, Anand R, Braunewell KH: Neuronal Ca2+ sensor protein VILIP-I affects CGMP signalling of guanylyl cyclase $B$ by regulating clathrin-dependent receptor recycling in hippocampal neurons. J Cell Sci 2005 , I | 8:2495-2505
68. Bertling E, Hotulainen P, Mattila PK, Matilainen T, Salminen M, Lappalainen P: Cyclase-associated protein I (CAPI) promotes cofilin-induced actin dynamics in mammalian nonmuscle cells. Mol Biol Cell 2004, 1 5:2324-2334.

69. Sankaranarayanan S, Atluri PP, Ryan TA: Actin has a molecular scaffolding, not propulsive, role in presynaptic function. Nat Neurosci 2003, 6:127-135.

70. Vilar M, Murillo-Carretero M, Mira H, Magnusson K, Besset V, Ibanez CF: BexI, a novel interactor of the p75 neurotrophin receptor, links neurotrophin signaling to the cell cycle. EMBO J 2006

7I. GrandPre T, Nakamura F, Vartanian T, Strittmatter SM: Identification of the Nogo inhibitor of axon regeneration as a Reticulon protein. Nature 2000, 403:439-444.

72. Clarke GA, Moss DJ: GP55 inhibits both cell adhesion and growth of neurons, but not non-neuronal cells, via a G-protein-coupled receptor. Eur J Neurosci 1997, 9:334-34I.

73. Buttery P, Beg AA, Chih B, Broder A, Mason CA, Scheiffele P: The diacylglycerol-binding protein $\{$ alpha\} $I$-chimaerin regulates dendritic morphology. Proc Natl Acad Sci U S A 2006, 103:1924-1929.

74. Morel N: Neurotransmitter release: the dark side of the vacuolar-H+ATPase. Biol Cell 2003, 95:453-457.

75. Frassoni C, Inverardi F, Coco S, Ortino B, Grumelli C, Pozzi D, Verderio C, Matteoli M: Analysis of SNAP-25 immunoreactivity in hippocampal inhibitory neurons during development in culture and in situ. Neuroscience 2005, I 3 I:813-823.

76. Aikawa Y, Lynch KL, Boswell KL, Martin TF: A Second SNARE Role for Exocytic SNAP25 in Endosome Fusion. Mol Biol Cell 2006, I 7:21 13-2124.

77. Fukuda M, Mikoshiba K: Characterization of KIAAI427 protein as an atypical synaptotagmin (Syt XIII). Biochem J 200I, 354:249-257

78. May AP, Whiteheart SW, Weis WI: Unraveling the mechanism of the vesicle transport ATPase NSF, the N-ethylmaleimidesensitive factor. J Biol Chem 2001, 276:21991-21994.

79. Alexianu ME, Mohamed AH, Smith RG, Colom LV, Appel SH: Apoptotic cell death of a hybrid motoneuron cell line induced by immunoglobulins from patients with amyotrophic lateral sclerosis. I Neurochem 1994, 63:2365-2368.

80. Fishman PS, Drachman DB: Internalization of IgG in motoneurons of patients with ALS: selective or nonselective? Neurology 1995, 45: I55I-I554.

8I. Fabian RH, Petroff G: Intraneuronal IgG in the central nervous system: uptake by retrograde axonal transport. Neurology 1987, 37:1780-1784.

82. Engelhardt Jl, Appel SH: IgG reactivity in the spinal cord and motor cortex in amyotrophic lateral sclerosis. Arch Neurol 1990, 47:1210-1216.

83. Smith RG, Alexianu ME, Crawford G, Nyormoi O, Stefani E, Appel $\mathrm{SH}$ : Cytotoxicity of immunoglobulins from amyotrophic lateral sclerosis patients on a hybrid motoneuron cell line. Proc Natl Acad Sci U S A 1994, 91:3393-3397.

84. Yi FH, Lautrette C, Vermot-Desroches C, Bordessoule D, Couratier $\mathrm{P}$, Wijdenes J, Preud'homme JL, Jauberteau MO: In vitro induction of neuronal apoptosis by anti-Fas antibody-containing sera from amyotrophic lateral sclerosis patients. J Neuroimmunol 2000, 109:21 I-220.

85. Pagani MR, Reisin RC, Uchitel OD: Calcium signaling pathways mediating synaptic potentiation triggered by amyotrophic lateral sclerosis IgG in motor nerve terminals. J Neurosci 2006 26:266|-2672.

86. Waragai M, Chiba A, Uchibori A, Fukushima T, Anno M, Tanaka K: Anti-Ma2 associated paraneoplastic neurological syndrome presenting as encephalitis and progressive muscular atrophy. J Neurol Neurosurg Psychiatry 2006, 77: I I I-I I3.

87. Voltz R, Gultekin SH, Rosenfeld MR, Gerstner E, Eichen J, Posner JB, Dalmau J: A serologic marker of paraneoplastic limbic and brain-stem encephalitis in patients with testicular cancer. $N$ Engl J Med 1999, 340: I788-1795.

88. Harada N, lijima S, Kobayashi K, Yoshida T, Brown WR, Hibi T, Oshima A, Morikawa M: Human IgGFc binding protein (FcgammaBP) in colonic epithelial cells exhibits mucin-like structure. J Biol Chem 1997, 272:15232-15241.

89. Kobayashi K, Yagasaki M, Harada N, Chichibu K, Hibi T, Yoshida T, Brown WR, Morikawa M: Detection of Fcgamma binding pro- 
tein antigen in human sera and its relation with autoimmune diseases. Immunol Lett 200I, 79:229-235.

90. Li R, Strohmeyer R, Liang Z, Lue LF, Rogers J: CCAAT/enhancer binding protein delta (C/EBPdelta) expression and elevation in Alzheimer's disease. Neurobiol Aging 2004, 25:991-999.

91. Kim YS, Jang SW, Sung HJ, Lee HJ, Kim IS, Na DS, Ko J: Role of I43-3 eta as a positive regulator of the glucocorticoid receptor transcriptional activation. Endocrinology 2005, 146:3 |33-3|40.

92. Siao C], Tsirka SE: Tissue plasminogen activator mediates microglial activation via its finger domain through annexin II. J Neurosci 2002, 22:3352-3358.

93. Roth J, Vogl T, Sorg C, Sunderkotter C: Phagocyte-specific SI 00 proteins: a novel group of proinflammatory molecules. Trends Immunol 2003, 24:155-158.

94. Ling Q, Jacovina AT, Deora A, Febbraio M, Simantov R, Silverstein RL Hempstead B, Mark WH, Hajjar KA: Annexin II regulates fibrin homeostasis and neoangiogenesis in vivo. J Clin Invest 2004, I I 3:38-48.

95. Tsirka SE: Tissue plasminogen activator as a modulator of neuronal survival and function. Biochem Soc Trans 2002, 30:222-225.

96. Viemann D, Strey A, Janning A, Jurk K, Klimmek K, Vogl T, Hirono K Ichida F, Foell D, Kehrel B, Gerke V, Sorg C, Roth J: Myeloidrelated proteins 8 and 14 induce a specific inflammatory response in human microvascular endothelial cells. Blood 2005, 105:2955-2962.

97. Uesugi M, Kasuya Y, Hayashi K, Goto K: SB209670, a potent endothelin receptor antagonist, prevents or delays axona degeneration after spinal cord injury. Brain Res 1998 786:235-239.

98. Lo AC, Chen AY, Hung VK, Yaw LP, Fung MK, Ho MC, Tsang MC, Chung SS, Chung SK: Endothelin-I overexpression leads to further water accumulation and brain edema after middle cerebral artery occlusion via aquaporin 4 expression in astrocytic end-feet. J Cereb Blood Flow Metab 2005, 25:998-I0II.

99. Rozyczka J, Figiel M, Engele J: Endothelins negatively regulate glial glutamate transporter expression. Brain Pathol 2004, 14:406-414.

100. Hasue F, Kuwaki T, Kisanuki YY, Yanagisawa M, Moriya H, Fukuda Y, Shimoyama M: Increased sensitivity to acute and persistent pain in neuron-specific endothelin-I knockout mice. Neuroscience 2005, 130:349-358.

I0I. Ho MC, Lo AC, Kurihara H, Yu AC, Chung SS, Chung SK: Endothelin-I protects astrocytes from hypoxic/ischemic injury. FASEB J 200I, 15:618-626.

102. Knowles J, Loizidou M, Taylor I: Endothelin-I and angiogenesis in cancer. Curr Vasc Pharmacol 2005, 3:309-3I4.

103. Okada M, Yan SF, Pinsky DJ: Peroxisome proliferator-activated receptor-gamma (PPAR-gamma) activation suppresses ischemic induction of Egr-I and its inflammatory gene targets. FASEB J 2002, 16:|86|-|868.

104. Fahmy RG, Dass CR, Sun LQ, Chesterman CN, Khachigian LM: Transcription factor Egr-I supports FGF-dependent angiogenesis during neovascularization and tumor growth. Nat Med 2003 9:1026-1032

105. Yoon JC, Chickering TW, Rosen ED, Dussault B, Qin Y, Soukas A, Friedman JM, Holmes WE, Spiegelman BM: Peroxisome proliferator-activated receptor gamma target gene encoding a novel angiopoietin-related protein associated with adipose differentiation. Mol Cell Biol 2000, 20:5343-5349.

106. Greenway MJ, Andersen PM, Russ C, Ennis S, Cashman S, Donaghy C Patterson V, Swingler R, Kieran D, Prehn J, Morrison KE, Green A, Acharya KR, Brown RH, Hardiman O: ANG mutations segregate with familial and 'sporadic' amyotrophic lateral sclerosis. Nat Genet 2006.

107. Oosthuyse B, Moons L, Storkebaum E, Beck H, Nuyens D, Brusselmans K, Van DJ, Hellings P, Gorselink M, Heymans S, Theilmeier G Dewerchin M, Laudenbach V, Vermylen P, Raat H, Acker T, Vleminckx V, Van Den BL, Cashman N, Fujisawa H, Drost MR, Sciot R, Bruyninckx F, Hicklin DJ, Ince C, Gressens P, Lupu F, Plate KH, Robberecht W, Herbert JM, Collen D, Carmeliet P: Deletion of the hypoxia-response element in the vascular endothelial growth factor promoter causes motor neuron degeneration. Nat Genet 200I, 28:131-138.

108. Penkowa M: Metallothioneins are multipurpose neuroprotectants during brain pathology. FEBS J 2006, 273:1857-| 870 .
109. Taylor DM, Minotti S, Agar JN, Durham HD: Overexpression of metallothionein protects cultured motor neurons against oxidative stress, but not mutant $\mathrm{Cu} / \mathrm{Zn}$-superoxide dismutase toxicity. Neurotoxicology 2004, 25:779-792

110. Morgan R, Sargent MG: The role in neural patterning of translation initiation factor elF4All; induction of neural fold genes. Development 1997, I 24:275 I-2760.

III. Cheyssac C, Dina C, Lepretre F, Vasseur-Delannoy V, Dechaume A, Lobbens S, Balkau B, Ruiz J, Charpentier G, Pattou F, Joly E, Prentki M, Hansen T, Pedersen O, Vaxillaire M, Froguel P: EIF4A2 Is a Positional Candidate Gene at the 3q27 Locus Linked to Type 2 Diabetes in French Families. Diabetes 2006, 55: I 17।-II76.

II2. Davies W, Smith RJ, Kelsey G, Wilkinson LS: Expression patterns of the novel imprinted genes Nap II5 and PegI3 and their non-imprinted host genes in the adult mouse brain. Gene Expr Patterns 2004, 4:74I-747.

I I3. Loyola A, Almouzni G: Histone chaperones, a supporting role in the limelight. Biochim Biophys Acta 2004, 1677:3-II.

114. Weinstein LS, Liu J, Sakamoto A, Xie T, Chen M: Minireview: GNAS: normal and abnormal functions. Endocrinology 2004, I 45:5459-5464.

115. Menzies FM, Cookson MR, Taylor RW, Turnbull DM, ChrzanowskaLightowlers ZM, Dong L, Figlewicz DA, Shaw PJ: Mitochondrial dysfunction in a cell culture model of familial amyotrophic lateral sclerosis. Brain 2002, I25: | 522-1533.

I 16. Singh P, Jain A, Kaur G: Impact of hypoglycemia and diabetes on CNS: correlation of mitochondrial oxidative stress with DNA damage. Mol Cell Biochem 2004, 260:153-159.

II7. Miyoshi N, Oubrahim H, Chock PB, Stadtman ER: Age-dependent cell death and the role of ATP in hydrogen peroxide-induced apoptosis and necrosis. Proc Natl Acad Sci U S A 2006, 103:1727-|73|.

1 18. Sanchez-Carbente MR, Massieu L: Transient inhibition of glutamate uptake in vivo induces neurodegeneration when energy metabolism is impaired. J Neurochem 1999, 72:129-138.

119. Miller G: Neuroscience. The dark side of glia. Science 2005, 308:778-78।

120. Moalem G, Tracey DJ: Immune and inflammatory mechanisms in neuropathic pain. Brain Res Brain Res Rev 2006, 5 I (2):240-64.

I2I. Montana $\mathrm{V}, \mathrm{Ni} Y$, Sunjara $\mathrm{V}$, Hua $\mathrm{X}$, Parpura $\mathrm{V}$ : Vesicular glutamate transporter-dependent glutamate release from astrocytes. J Neurosci 2004, 24:2633-2642.

122. Fellin T, Pascual O, Haydon PG: Astrocytes coordinate synaptic networks: balanced excitation and inhibition. Physiology (Bethesda) 2006, $21: 208-215$.

123. Traynor BJ, Bruijn L, Conwit R, Beal F, O'Neill G, Fagan SC, Cudkowicz ME: Neuroprotective agents for clinical trials in ALS: a systematic assessment. Neurology 2006, 67:20-27.

124. Chen X, Ji ZL, Chen YZ: TTD: Therapeutic Target Database. Nucleic Acids Res 2002, 30:4I2-4I5.

125. Wishart DS, Knox C, Guo AC, Shrivastava S, Hassanali M, Stothard $P$, Chang Z, Woolsey J: DrugBank: a comprehensive resource for in silico drug discovery and exploration. Nucleic Acids Res 2006, 34:D668-D672.

126. Chin K, Channick R: Bosentan. Expert Rev Cardiovasc Ther 2004, 2: $175-182$.

127. Morihara T, Teter B, Yang F, Lim GP, Boudinot S, Boudinot FD, Frautschy SA, Cole GM: Ibuprofen suppresses interleukin-I beta induction of pro-amyloidogenic alphal-antichymotrypsin to ameliorate beta-amyloid (Abeta) pathology in Alzheimer's models. Neuropsychopharmacology 2005, 30: IIII-II 20.

128. Petroski RE, Pomeroy JE, Das R, Bowman H, Yang W, Chen AP, Foster AC: Indiplon is a high-affinity positive allosteric modulator with selectivity for \{alpha\} I subunit containing GABAA receptors. J Pharmacol Exp Ther 2006, 3 I 7:369-377.

129. Barrett T, Suzek TO, Troup DB, Wilhite SE, Ngau WC, Ledoux P, Rudnev D, Lash AE, Fujibuchi W, Edgar R: NCBI GEO: mining millions of expression profiles--database and tools. Nucleic Acids Res 2005, 33:D562-D566.

130. Doniger SW, Salomonis N, Dahlquist KD, Vranizan K, Lawlor SC Conklin BR: MAPPFinder: using Gene Ontology and GenMAPP to create a global gene-expression profile from microarray data. Genome Biol 2003, 4:R7.

13I. Ashburner M, Ball CA, Blake JA, Botstein D, Butler H, Cherry JM, Davis AP, Dolinski K, Dwight SS, Eppig JT, Harris MA, Hill DP, IsselTarver L, Kasarskis A, Lewis S, Matese JC, Richardson JE, Ringwald M, 
Rubin GM, Sherlock G: Gene ontology: tool for the unification of biology. The Gene Ontology Consortium. Nat Genet 2000, 25:25-29.

132. Salomonis N, Cotte N, Zambon AC, Pollard KS, Vranizan K, Doniger SW, Dolganov G, Conklin BR: Identifying genetic networks underlying myometrial transition to labor. Genome Biol 2005, 6:RI2.

133. Zambon AC, McDearmon EL, Salomonis N, Vranizan KM, Johansen KL, Adey D, Takahashi JS, Schambelan M, Conklin BR: Time- and exercise-dependent gene regulation in human skeletal muscle. Genome Biol 2003, 4:R6I.

134. Zhao W, Meiri N, Xu H, Cavallaro S, Quattrone A, Zhang L, Alkon $D L$ : Spatial learning induced changes in expression of the ryanodine type II receptor in the rat hippocampus. FASEB J 2000, I 4:290-300.

135. Eyre TA, Ducluzeau F, Sneddon TP, Povey S, Bruford EA, Lush MJ: The HUGO Gene Nomenclature Database, 2006 updates. Nucleic Acids Res 2006, 34:D319-D32I.

Publish with Bio Med Central and every scientist can read your work free of charge

"BioMed Central will be the most significant development for disseminating the results of biomedical research in our lifetime. "

Sir Paul Nurse, Cancer Research UK

Your research papers will be:

- available free of charge to the entire biomedical community

- peer reviewed and published immediately upon acceptance

- cited in PubMed and archived on PubMed Central

- yours - you keep the copyright

Submit your manuscript here:

http://www.biomedcentral.com/info/publishing_adv.asp
BiolMedcentral 